\title{
An Intentional Tort Theory of Patents
}

Saurabh Vishnubhakat

Texas A\&M University School of Law, sv10@law.tamu.edu

Follow this and additional works at: https://scholarship.law.tamu.edu/facscholar

Part of the Intellectual Property Law Commons, and the Torts Commons

\section{Recommended Citation}

Saurabh Vishnubhakat, An Intentional Tort Theory of Patents, 68 Fla. L. Rev. 571 (2016).

Available at: https://scholarship.law.tamu.edu/facscholar/1051

This Article is brought to you for free and open access by Texas A\&M Law Scholarship. It has been accepted for inclusion in Faculty Scholarship by an authorized administrator of Texas A\&M Law Scholarship. For more information, please contact aretteen@law.tamu.edu. 


\title{
AN INTENTIONAL TORT THEORY OF PATENTS
}

\author{
Saurabh Vishnubhakat
}

\begin{abstract}
This Article challenges the dogma of U.S. patent law that direct infringement is a strict liability tort. Impermissibly practicing a patented invention does create liability even if the infringer did not intend to infringe or know about the patent. The consensus is that this is a form of strict liability. The flaw in the consensus is that it proves too little, for the same is true of intentional torts: intent to commit the tort is unnecessary, and ignorance of the legal right is no excuse. What is relevant is intent to perform the action that the law deems tortious. So for the tort of patent infringement, the question is whether liability should require that the infringer intended to perform the actions that constitute infringement. The patent statute and the few cases that have broached the question suggest the answer is yes-tortious intent should be necessary. However, patent law currently takes no position on tortious intent. The strict liability view is merely a default. This Article fills that gap by applying ordinary tort principles to patent infringement. The proposed framework offers a powerful policy lever for important issues implicating the notice function of patents, including divided infringement, claim construction, and inherency. This framework also mitigates the effects of patent assertion on risk allocation in the patent system by differentiating among makers, sellers, and users of patented innovation - a distinction that is economically important but has no principled basis in patent doctrine.
\end{abstract}

INTRODUCTION 573

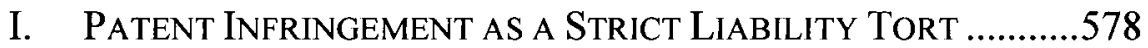

A. The Central Dogma ......................................................578

1. The Strict Liability View in Patent Law .................578

2. Departures from Strict Liability in Patent Law

* Associate Professor of Law, Texas A\&M University School of Law; Fellow, Duke Law Center for Innovation Policy. Sincere thanks to Arti Rai for invaluable discussion and guidance, and to Stuart Benjamin, Joseph Blocher, Jamie Boyle, Michael Burstein, Tun-Jen Chiang, Eric Claeys, Kevin Collins, David Darwin, Edward Elliott, Michael Frakes, Patrick Goold, Stuart Graham, Ariel Katz, Anna Laakman, David Levine, Oskar Liivak, Jake Linford, Ben Liu, Alan Marco, Adam Mossoff, Lateef Mtima, Chris Newman, Laura Pedraza-Fariña, Jason Rantanen, Barak Richman, Michael Risch, Betsy Rosenblatt, Rachel Sachs, Josh Sarnoff, Jacob Sherkow, and Susan Yeh for thoughtful comments. This project has benefited from workshop-format presentations at the 2014 Drake IP Scholars Roundtable; the 14th IP Scholars Conference at University of California, Berkeley; the Duke University School of Law; and the George Mason University School of Law. 
3. Doubling Down on Strict Liability ........................583

4. What Strict Liability Really Means.........................586

B. The Overburdened Notice Requirement .........................591

1. Two Metaphors of Patent Notice ...........................591

2. Notice of Claim Scope .............................................593

II. AN INTENTIONAL TORT THEORY OF INFRINGEMENT ...............598

A. Tort and the Exercise of Agency...................................598

1. A Brief History of Tort ..........................................599

2. Gradations of Tortious Intent ..................................600

3. The Instructive Case of Trespass to Land ................601

B. Tortious Intent in Patent Infringement ...........................605

1. The Statutory Basis for Tortious Intent ....................605

2. The Common Law Basis for Tortious Intent ...........607

III. TOWARD A NEW VIEW OF DIRECT INFRINGEMENT ..................610

A. Direct Infringement as an Intentional Tort ......................610

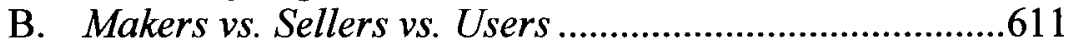

1. Intent to Make an Invention ......................................611

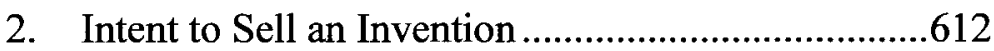

3. Intent to Use an Invention .....................................612

C. Inherency and the Anticipation-Infringement

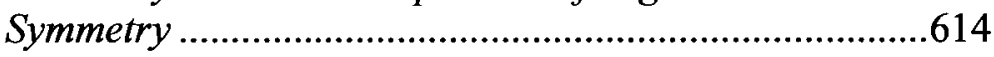

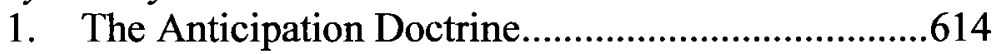

2. The Inherency Doctrine .............................................615

3. The Role of Tortious Intent......................................616

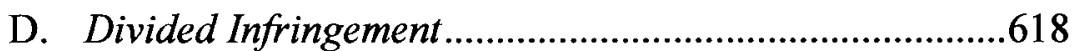

1. Akamai and the Single-Entity Rule .........................618

2. The Role of Tortious Intent..................................619

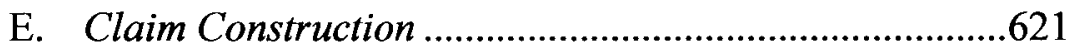

1. Linguistic vs. Purposive Construction ....................621

2. The Role of Tortious Intent.......................................624

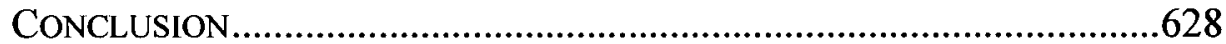




\section{INTRODUCTION}

It is conventional wisdom in patent law that direct infringement is a strict liability tort. ${ }^{1}$ A patent creates a right to exclude others from making, selling, or using the patented invention. ${ }^{2}$ Performing any of these activities-practicing the patented invention-without the patent owner's permission is direct infringement of the patent. ${ }^{3}$ Infringing in this way creates liability even if the infringer did not intend to commit infringement or even know of the patent. ${ }^{4}$ If the infringer did intend to infringe or did know of the patent, then enhanced damages may be available for willful infringement. ${ }^{5}$ But the underlying direct infringement requires neither. ${ }^{6}$ These are the basic precepts of patent infringement. By the consensus view of patent law, these precepts amount to strict liability. ${ }^{7}$

This consensus view is an unfortunate caricature of strict liability. Indeed, these precepts would be just as true if direct infringement were an intentional tort. Intentional torts, too, do not require intent to commit a tort or any knowledge that a legal right exists. ${ }^{8}$ What is relevant is the tortfeasor's intent to perform an act that the law deems tortious. ${ }^{9}$ If direct infringement were an intentional tort, an infringer could still be liable without intending to infringe the patent and without knowing that the patent exists, so long as she intended to perform one of the actions that constitute infringement: making, selling, or using the patented invention. So, is patent infringement a strict liability tort, as patent law currently contends, or an intentional tort, which is just as plausible under the basic precepts of infringement? To decide, patent law must answer an

1. See, e.g., Hilton Davis Chem. Co. v. Warner-Jenkinson Co., 62 F.3d 1512, 1527 (Fed. Cir. 1995) ("Infringement . . . is a strict liability offense."), rev'd on other grounds, 520 U.S. 17, 34-35 (1997).

2. 35 U.S.C. $\$ 271$ (a) (2012). The patent owner may also exclude others from offering the invention for sale or from importing the invention into the United States. Id. As a shorthand, this Article refers to "making, selling, and using," except when analyzing the statutory text itself. See infra Subsection II.B.1.

3. 35 U.S.C. $\$ 271(\mathrm{a})$.

4. Jurgens v. CBK, Ltd., 80 F.3d 1566, 1570 n.2 (Fed. Cir. 1996) (explaining that patent infringement's so-called strict liability character obliges courts to grant relief "regardless of the intent, culpability or motivation of the infringer").

5. Smith v. Alyeska Pipeline Serv. Co., 538 F. Supp. 977, 986 (D. Del. 1982).

6. See Hilton Davis, 62 F.3d at 1527.

7. See, e.g., A. Samuel Oddi, Contributory Infringement/Patent Misuse: Metaphysics and Metamorphosis, 44 U. PITT. L. REv. 73, 87 (1982) (referring to direct infringement under 35 U.S.C. $\S 271$ (a) as a strict liability tort).

8. See Restatement (SECOND) OF TORTS $§ 8$ A (AM. LAW INST. 1965).

9. Id. ("The word 'intent' is used throughout the Restatement of this Subject to denote that the actor desires to cause consequences of his act, or that he believes that the consequences are substantially certain to result from it."). 
important doctrinal question: should direct infringement liability require that the alleged infringer intended to perform the actions that constitute infringement?

If the answer is yes, then direct infringement is an intentional tort, but only in the ordinary sense that unintended actions cannot form the basis for liability. In fact, the patent statute supports this reading, as do the few judicial opinions that have implicitly addressed it. Those opinions found non-infringement because there was no tortious intent to perform the actions that infringed. ${ }^{10}$ This reasoning indicates that tortious intent is, indeed, necessary. However, if the answer is no, then even unintended actions can form the basis for direct infringement liability. Such a regime would be purely distributive, allocating cost and risk to the public without any respect for autonomy, personal agency, or purposive action. Nevertheless, though infringement doctrine routinely refers to strict liability, patent law does not currently say that the answer to the doctrinal question is no. Until now, patent law has ignored the question altogether. The consensus is nothing more than a default.

The effects of this analytical gap are profound. By failing to answer the necessary doctrinal question about intended actions, while uncritically repeating the rhetoric of strict liability, patent law always risks drifting toward the latter, distributive regime of direct infringement. In that world, adequate public notice about the existence and boundaries of patent rights is essential to justifying the patent system, but virtually impossible to achieve. If someone may become liable for infringing a patent without any general or specific intent to perform the relevant actions, then the public bears all the cost and risk of avoiding actions that may turn out to infringe. As a result, the patent system must make abundantly clear ex ante the existence and scope of patent rights. The most forceful evidence of patent failure is notice failure, particularly where it benefits so-called patent trolls who trade on information asymmetries and ambiguities about the scope of patent rights. But if that world is largely the one in which we already live, it is not because patent law has broadly made the wrong normative choice about whether infringement should require intended actions. It is because patent law has failed to choose.

The purpose of this Article is to raise that question and to answer yes. Direct infringement liability should require an underlying intent to make, sell, or use the patented invention-intent to perform the actions that constitute the tort of direct patent infringement. To clarify, this is simply tortious intent to perform certain actions, not the altogether different intent to commit infringement, which patent law separately penalizes

10. See, e.g., Brothers v. United States, 52 Ct. Cl. 462,467 (1917). 
under the remedial doctrine of willful infringement and which would remain unnecessary for liability. ${ }^{11}$ Patent law's ignorance of this distinction has created a number of normative problems by default. ${ }^{12}$ If, upon asking the question about intended actions, patent law now chooses to disregard the relevant intent behind actions that constitute infringement, then those normative problems will only become formalized and worsen.

A first problem with disregarding tortious intent is that there is no principled basis for differentiating among different kinds of actors in the patent system based on their actions. This distinction is economically significant because the kinds of actions that can give rise to infringement occupy very different positions in the stream of commerce. ${ }^{13}$ Such actions also reflect divergent calculations of cost, risk, and reward. As a result, makers, sellers, and users all have their own distinct approaches to conducting patent searches and clearances, avoiding infringement, and even forgoing economically productive activity in some cases.

For example, a complex and highly integrated product such as a tablet computer presents very different infringement risks for the various actors who cross paths with a single patented component of the tablet, such as a piece of storage hardware. The manufacturer of the component is likely to have considerable knowledge about its design and operation. As a result, the manufacturer's act of making the component is likely to be intentional, even if the manufacturer is unaware of any relevant patents. By contrast, the downstream retailer of the fully manufactured tablet is less likely to know about the particular storage component when selling the tablet. As a result, the retailer's act of selling the tablet is less likely to be intentional with respect to the component. And the end purchaser, concerned broadly with the tablet and likely ignorant of its inner workings, is probably the most poorly positioned to act with tortious intent as to the component when using the tablet. To sum up these differences, the manufacturer has the lowest information cost for avoiding infringement; the end user, the highest cost. It is therefore unsound policy to treat all of these actors as interchangeable potential infringers. However, differentiating among them necessarily means taking account of their various incentives to perform particular kinds of

11. Smith v. Alyeska Pipeline Serv. Co., 538 F. Supp. 977, 986 (D. Del. 1982).

12. A broader set of critiques is also emerging around the incoherent roles of tortious intent in copyright infringement and trademark infringement, with calls for greater analytical precision about the tort theory underlying these doctrines. See, e.g., Patrick R. Goold, Is Copyright Infringement a Strict Liability Tort?, 30 BERKELEY TECH. L.J. 305, 352-53 (2015); David Welkowitz, Fault Lines in Trademark Default Judgments, 22 J. INTELL. Prop. L. 101, 107-08 (2014).

13. See infra Section III.B. 
actions that may infringe. The doctrine of tortious intent resolves that analytical problem, ${ }^{14}$ particularly for the prominent policy challenge of managing end user liability. ${ }^{15}$

A second problem with disregarding tortious intent is that it indiscriminately imposes infringement liability on actions that are purely inadvertent or even unforeseeable, such as unexpectedly producing trace amounts of a chemical that happens to be patented in an otherwise permissible industrial process. ${ }^{16}$ Importantly, shielding inadvertent actions is a different question from that of shielding inadvertent infringement, which refers more broadly to all actions (whether intentional or not) that take place in ignorance of others' patent rights.

For example, one type of inadvertent infringement may be for a firm to carry out an industrial process designed to produce Chemical A but which unexpectedly produces a different Chemical B that, unbeknownst to the firm, turns out to be patented. Another type of inadvertent infringement may be for the firm deliberately to perform a method of measuring drug levels in the bloodstreams of patients and adjusting drug dosage accordingly, a method that unwittingly turns out to infringe a patent. In the former example, the act of producing Chemical $\mathrm{B}$ is inadvertent because the infringing compound was not an intended product of the process. The infringement is also inadvertent because the firm was unaware of the patent. In the latter example, the actions of measuring drug levels and adjusting dosage are intentional, and only the infringement is inadvertent. Some scholars, agencies, and legislators support immunizing even the latter, broader set where only the infringement is inadvertent. There is, therefore, at least as much support for immunizing actions that are purely inadvertent. Yet such immunity necessarily means asking whether the actor intended to commit such tortious actions. The doctrine of tortious intent also resolves this analytical problem of inadvertence, one that is especially pressing after problematic judicial precedents regarding the inherency doctrine. ${ }^{17}$

A third problem with disregarding tortious intent is that it aggravates the systemic challenge of divided infringement, which arises when separate actions of multiple parties collectively infringe a patent. The U.S. Supreme Court faced the issue during the October 2013 Term in Limelight Networks, Inc. v. Akamai Technologies, Inc. ${ }^{18}$ after the U.S. Court of Appeals for the Federal Circuit produced a fractured en banc

14. See infra Section III.A.

15. See infra Subsection III.B.3.

16. E.g., SmithKline Beecham Corp. v. Apotex Corp., 403 F.3d 1328, 1330 (Fed. Cir. 2005) (Newman, J., dissenting).

17. See infra Section III.C.

18. 134 S. Ct. 2111 (2014). 
decision. ${ }^{19}$ However, the Court's opinion left open the fundamental question of how to decide whether to consider the conduct of multiple accused parties collectively. ${ }^{20}$ Without a principled basis for making this decision, courts necessarily risk crafting an error-prone rule. If the rule is over-inclusive, it will impose liability on wholly unrelated actors practicing freely available inventions. ${ }^{21}$ If the rule is under-inclusive, it will condone the violation of patent rights through strategically divided actions among parties acting deliberately in concert. ${ }^{22}$ The doctrine of tortious intent resolves this dilemma and offers the only principled way to do so. ${ }^{23}$

A fourth problem is claim construction, which underlies all legal and factual conclusions of patent validity as well as the risk and actual occurrence of infringement. Claim construction poses a number of subsidiary questions, including how to construe claims in the first place, how horizontally to address prior constructions among district courts and administrative tribunals, and how vertically to address on appeal the constructions of lower courts. These questions reflect policy concerns about understanding patent boundaries accurately and precisely as well as about allocating decision-making authority between trial and appellate courts and between judicial and administrative institutions. Prominent among these concerns is the propriety of the purposive approach to claim construction. Purposive construction derives meaning from the patent text based on the purposes for which the patent was constituted, namely to protect the inventor's invention. ${ }^{24}$ The approach remains controversial, and even courts that engage in it do not always do so transparently. The doctrine of tortious intent is consonant with purposive construction and offers a coherent justification for it. ${ }^{25}$

In sum, this Article fills the analytical gap in direct patent infringement through the doctrine of tortious intent. Application of the doctrine proceeds from ordinary tort principles, the text of the Patent Act itself, and the few patent decisions that have examined intent to perform actions relevant to infringement. The result is a powerful new policy lever in current debates about patent notice and the effect of patent litigation on static and dynamic efficiency in the patent system.

This Article proceeds in three parts. Part I shows that the current view of patent infringement as a strict liability tort reflects a misunderstanding

19. See Akamai Techs., Inc. v. Limelight Networks, Inc., 692 F.3d 1301, 1305 (Fed. Cir. 2012) (en banc) (per curiam), rev'd, 134 S. Ct. 2111 (2014).

20. Id. at 132 I (Newman, J., dissenting).

21. See infra Section III.A.

22. See infra Section III.A.

23. See infra Section III.A.

24. See infra Subsection III.E.2.

25. See infra Subsection III.E.2. 
of tort law principles and discusses the normative implications of this mistake. Part II derives a theory of tortious intent based on a correspondence between the extent of a tortfeasor's liability and the level of purposive action involved in her commission of the tort. Part III applies this theory to direct infringement, explains how requiring tortious intent for direct infringement liability is analytically consonant with other patent law doctrines, and discusses four major policy benefits that the doctrine of tortious intent offers for patent notice and abusive patent litigation.

\section{Patent Infringement as a Strict Liability Tort}

As for the basic act of direct infringement, there is a widespread view that patent law, when imposing liability, takes no account of intent to infringe the patent or of knowledge that the patent even exists. ${ }^{26}$ These facts are relevant only to identify indirect forms of infringement or to determine the appropriate remedy. Accordingly, commentators and even courts routinely refer to direct patent infringement as a strict liability offense. ${ }^{27}$

\section{A. The Central Dogma}

This practice of referring to strict liability as the doctrinal baseline of infringement while sometimes departing from strict liability does not survive closer scrutiny. Evaluating recent Supreme Court case law reveals the conceptual incoherence of the strict liability dogma and invites a more careful look at what strict liability would actually mean.

\section{The Strict Liability View in Patent Law}

Historically, the disregard for intent to infringe and for knowledge of the patent has long been a rule of U.S. patent infringement law, with cases as early as the 1840s taking as given that one "may have infringed without intending, or even knowing it; but he is not, on that account, the less an infringer." 28 By the time Professor Albert Walker first published his 1883 treatise on patent law, it was well established that infringement required neither knowledge of the patent nor appreciation that one's act constituted infringement. ${ }^{29}$ Subsequent editions affirmed this understanding and

26. See, e.g., Jurgens v. CBK, Ltd., 80 F.3d 1566, 1570 n.2 (Fed. Cir. 1996).

27. See, e.g., Hilton Davis Chem. Co. v. Warner-Jenkinson Co., 62 F.3d 1512, 1527 (Fed. Cir. 1995), rev'd on other grounds, 520 U.S. 17, 34-35 (1997).

28. Parker v. Hulme, 18 F. Cas. 1138,1143 (C.C.E.D. Pa. 1849) (No. 10,740); see also Parker v. Haworth, 18 F. Cas. 1135, 1136 (C.C.D. Ill. 1848) (No. 10,738) (instructing that "[t]he defendant may not have been aware of the plaintiff's right").

29. Albert H. Walker, Text-Book of the Patent Laws of the United States of AMERICA $\S 377$ (1 st ed. 1883). 
further clarified that independent invention without any knowledge of an existing patent did not avert infringement. ${ }^{30}$ However, as early as Professor William Robinson's 1890 treatise, the general body of law disregarding infringer intent already included an exception for what would later become the doctrine of contributory infringement:

But there are many actions, equivocal in character so far as the external operation is concerned, which are or are not acts of infringement according to the object contemplated by their actor,- -actions otherwise innocent thus being regarded as violations of the rights secured by the patent, when intended as parts of a transaction which taken as a whole would be an infringement. ${ }^{31}$

Professor Robinson discussed these equivocal actions - infringement by unlawful making, unlawful using, and unlawful selling - as part of a unitary doctrine for capturing direct and contributory infringers, ${ }^{32}$ and therefore asserted a role for intent that "has not been borne out by subsequent developments." ${ }^{33}$ For example, his discussion of infringement by unlawful making contemplates distinctions between making as a construction and making as a repair, ${ }^{34}$ a distinction whose current form does not consider the infringer's intent at all. ${ }^{35}$ His discussion also contemplates permissible makings for experimental purposes, though the experimental use exception is widely regarded as all but a dead letter, ${ }^{36}$ particularly after the Federal Circuit's decision in Madey v. Duke University. ${ }^{37}$ Nevertheless, Professor Robinson's evaluation of allegedly infringing actions based on "the object contemplated by their actor" is not wholly misplaced, as it reflects an intuitive distinction between intending to infringe and intending to perform actions that constitute infringement, a distinction as meaningful as it is overlooked. ${ }^{38}$

30. See 3 anthony W. Deller, Walker on Patents: Deller's Edition $\$ 453$ (1937); Albert H. WALKER, TEXT-BOOK OF THE LAW OF PATENTS FOR INVENTIONS $\$ 377$ (5th ed. 1917); Albert H. Walker, A Treatise ON The Law of Patents For InVEnTIONS $\$ 433$ (6th ed. 1929).

31. 3 William C. Robinson, The Law of Patents For USEFul InVEntions $\$ 901$ (1890).

32. See id. $\$ \$ 903-06$.

33. 4 R. CARL Moy, Moy's Walker on Patents $\$ 14: 17$ (Westlaw 4th ed. 2015).

34. 3 ROBINSON, supra note $31, \$ 903$.

35. See Jazz Photo Corp. v. Int'l Trade Comm'n, 264 F.3d 1094, 1105-06 (Fed. Cir. 2001) (discussing the repair-reconstruction dichotomy).

36. See, e.g., Sapna Kumar, Life, Liberty, and the Pursuit of Genetic Information, 65 ALA. L. REV. 625, 678 (2014).

37. 307 F.3d 1351, 1362 (Fed. Cir. 2002) (holding that use is not experimental if it is "in keeping with the legitimate business of the alleged infringer"); see also Kumar, supra note 36, at 678-79 (arguing for a statutory research exemption after the Madey decision).

38. See infra Subsection I.A.3. 
Apart from the general acceptance that intent is irrelevant to direct infringement, the designation of this principle as a form of strict liability is also widespread, though not as long-established. This vocabulary of strict liability pervades the scholarly discussion of both patent infringement ${ }^{39}$ and analogous infringements of other intellectual property rights. ${ }^{40}$ In the face of this literature framing patent infringement as a strict liability tort, courts in the last twenty years have followed suit. ${ }^{41}$ The Federal Circuit has even elaborated further, discussing strict liability not only as a characterization to be inferred from the historical disregard for both intent to infringe and knowledge of the patent, but also as a premise to guide both the infringement analysis itself ${ }^{42}$ and the resolution of related issues such as evidentiary relevance. ${ }^{43}$

\section{Departures from Strict Liability in Patent Law}

Still, despite this adherence to a strict liability conception of direct patent infringement, not all violations of patent rights give rise to strict liability, and the strict liability designation carries caveats in the literature. Willful infringement, induced infringement, and contributory infringement all require some level of purposive action, such as

39. See, e.g., Oddi, supra note 7, at 87.

40. See, e.g., A. Samuel Oddi, Contributory Copyright Infringement: The Tort and Technological Tensions, 64 NOTRE DAME L. REv. 47, 52 n.29 (1989) (arguing that direct infringement incurs strict liability not only for patents but also for trademarks and copyrights); Thornton Robison, The Confidence Game: An Approach to the Law About Trade Secrets, 25 ARIZ. L. REv. 347, 381 n. 162 (1983) (comparing a potential strict liability rule for innocent unauthorized use of trade secrets with the accepted strict liability rule of action for direct patent infringement under $\S 271(\mathrm{a})$ ). Notably, independent creation is a defense to infringement in copyright and trade secrecy, necessarily moderating the practical reach of any discussion regarding infringer intent. Id.

41. See, e.g., Hilton Davis Chem. Co. v. Warner-Jenkinson Co., 62 F.3d 1512, 1527 (Fed. Cir. 1995) (noting, with respect to the doctrine of equivalents, that "[i]nfringement is, and should remain, a strict liability offense"), rev'd on other grounds, 520 U.S. 17, 34-35 (1997) (accepting the Federal Circuit's intent-neutral view of infringement-notably, without using the language of strict liability).

42. See Jurgens v. CBK, Ltd., 80 F.3d 1566, 1570 n.2 (Fed. Cir. 1996) (explaining that patent infringement's so-called strict liability character obliges courts to grant relief "regardless of the intent, culpability or motivation of the infringer").

43. See, e.g., Intervet, Inc. v. Merial Ltd., 256 F.R.D. 229, 232 (D.D.C. 2009). In pertinent part, the court in Intervet held that a disputed interrogatory was relevant and therefore discoverable. Id. The interrogatory inquired about the circumstances under which the alleged infringer became aware of the patent-in-suit. Id. at 231. The court recognized that information is relevant under Federal Rule of Evidence 401 if "it is likely to make a material fact more or less likely," and awareness of the patent could be material or not depending on whether the patentee had alleged direct infringement alone (immaterial) or something more, requiring knowledge of the patent or intent to infringe (material). Id. at 232 . Notably, the court expressly invoked the "strict liability" view of direct infringement. Id. 
recklessness or actual intent, or some level of knowledge such as constructive or actual notice that the patent exists and is infringed. ${ }^{44}$ Yet even these modest departures only underscore the more fundamental mistake of regarding the basic act of direct infringement a strict liability tort.

Liability for willful infringement arises only where an infringer acts recklessly, that is, "despite an objectively high likelihood that its actions constituted infringement of a valid patent." manner does not itself create infringement liability - that threshold issue is still regarded as one of strict liability - but may warrant the imposition of enhanced damages up to threefold what the judge or jury assesses under 35 U.S.C. $\S 284 .{ }^{46}$ Seagate overruled the previous willful infringement standard set forth in Underwater Devices Inc. v. MorrisonKnudsen $\mathrm{Co}^{47}$ that a potential infringer with "actual notice of another's patent rights ... has an affirmative duty to exercise due care to determine whether or not he is infringing." its progeny included a duty to obtain competent advice of counsel prior. to any possible infringing activity ${ }^{49}$ and the possibility that an absence of legal counsel could imply willfulness, ${ }^{50}$ though the Federal Circuit later relaxed the drawing of such adverse inferences. ${ }^{51}$ Thus, whereas Underwater Devices required actual notice of the patent but only negligence with regard to determining and avoiding infringement, ${ }^{52}$ Seagate requires recklessness with regard to determining and avoiding infringement but has no explicit requirement as to notice. ${ }^{53}$ Under the "objectively high likelihood of infringement" standard in Seagate, a willful infringer will either ignore the likelihood that a known patent will be infringed or the likelihood that a relevant patent exists at all. For example, given a technology space crowded with many patents, Seagate might well support a finding of recklessness, and therefore of willful

44. See infra notes $45-62$ and accompanying text.

45. See In re Seagate Tech., LLC, 497 F.3d 1360, 1371 (Fed. Cir. 2007).

46. Id. at 1368 \& n.3 (noting that " $[\mathrm{b}]$ ecause patent infringement is a strict liability offense, the nature of the offense is only relevant in determining whether enhanced damages are warranted").

47. 717 F.2d 1380 (Fed. Cir. 1983).

48. Id. at 1389 .

49. Electro Med. Sys., S.A. v. Cooper Life Scis., Inc., 34 F.3d 1048, 1056 (Fed. Cir. 1994).

50. Kloster Speedsteel AB v. Crucible Inc., 793 F.2d 1565, 1579-80 (Fed. Cir. 1986).

51. Knorr-Bremse Systeme Fuer Nutzfahrzeuge GmbH v. Dana Corp., 383 F.3d 1337, 1345-46 (Fed. Cir. 2004) (en banc).

52. Underwater Devices, 717 F.2d at 1389-90.

53. In re Seagate Tech., LLC, 497 F.3d 1360, 1371 (Fed. Cir. 2007). 
infringement, based on a failure to conduct a patent search. ${ }^{54}$

By contrast, liability for induced infringement requires that the alleged inducer knew that the actions she induced constituted infringement. ${ }^{55}$ However, actual knowledge of the patent's existence is not necessary: it is enough that the alleged inducer believed there was a high probability that the combination of the components was patented and took deliberate steps to avoid actual knowledge of that fact. ${ }^{56}$ Liability for contributory infringement has an even higher standard. This standard requires that the alleged contributor actually knew that the combination to which her component contributed was both patented and infringing. ${ }^{57}$

Thus, the statutory actions for induced and contributory infringement are meaningfully different from the common law remedial basis of willful infringement. ${ }^{58}$ One result of this difference is that, read in pari materia with 35 U.S.C. $\$ 271$ (a), which defines infringement as a basic matter, ${ }^{59}$ both the induced and contributory infringement statutes require an underlying direct infringement. ${ }^{60} \mathrm{~A}$ second result of this difference is that, for willful infringement, courts may more readily reshape the necessary level of knowledge about the existence or infringement of a patent or of

54. See Tomita Techs. USA, LLC v. Nintendo Co., No. 11-4256, 2012 WL 2524770, at *10 (S.D.N.Y. June 26, 2012). The court in Tomita explained:

While an alleged infringer may often need to know of a patent's existence and scope in order to adequately comprehend the risk she faces, this case amply demonstrates that, in certain circumstances, an alleged infringer can know of an "objectively high likelihood" of infringement even though she does not know that the relevant patent has issued.

Id. at *10. But see Robocast, Inc. v. Microsoft Corp., 21 F. Supp. 3d 320, 335 (D. Del. 2014) (distinguishing Tomita, the court in Robocast did not find it necessary that an alleged infringer conduct a patent search, stating "[i]t seems contrary to waive the requirement for a noninfringement opinion when the defendant has knowledge of the patent and yet require a defendant to undertake a search to see if a patent existed in the first place").

55. Global-Tech Appliances, Inc. v. SEB S.A., 131 S. Ct. 2060, 2068 (2011).

56. Id. at 2070-71.

57. Aro Mfg. Co. v. Convertible Top Replacement Co., 377 U.S. 476, 488 (1964) (“Aro II").

58. The Patent Act creates induced infringement liability in $\S 271(\mathrm{~b})$ and contributory infringement liability in $\$ 271(\mathrm{c})$.

59. 35 U.S.C. $\$ 271(\mathrm{a})$.

60. Mirror Worlds, LLC v. Apple Inc., 692 F.3d 1351, 1359-60 (Fed. Cir. 2012) (explaining that "[i]nducement of infringement requires that there be a showing of an underlying act of direct infringement"); Aro II, 377 U.S. at 483 ("[I]t is settled that if there is no direct infringement of a patent there can be no contributory infringement." (quoting Aro Mfg. Co. v. Convertible Top Replacement Co., 365 U.S. 336, 341 (1961) ("Aro I"))). 
intent that can be inferred from that knowledge. ${ }^{61}$ For induced and contributory infringement, however, the levels of intent that are more directly implicated in the statutory text make such common law revision both more unlikely to occur and more incremental when they do. ${ }^{62}$

These various heightened requirements of knowledge and intent for imposing liability for indirect patent infringement have also been the subject of thoughtful academic discussion. Notable among this discussion are arguments to reformulate the conception of fault away from a mental state inquiry, ${ }^{63}$ to explore the potential inaptitude of culpability or intent in quantum-mechanical arts such as nanotechnology, ${ }^{64}$ and even to recast the current patent infringement system as one of "modified strict liability," often requiring notice of the patent. ${ }^{65}$ Like the case law, however, these arguments accept as given that the underlying act of direct infringement is a strict liability tort for which liability itself does not require any intent to infringe nor any notice or knowledge of the patent or its infringement. ${ }^{66}$

\section{Doubling Down on Strict Liability}

The rhetoric and implications of strict liability in patent infringement are even more salient after the Supreme Court's recent decision in Commil USA, LLC v. Cisco Systems, Inc. ${ }^{67}$ The dispute in Commil was one of induced infringement, ${ }^{68}$ but the posture of the case raised a side

61. See In re Seagate Tech., LLC, 497 F.3d 1360, 1371 (Fed. Cir. 2007) (expressly overruling the standard for willful infringement set forth in Underwater Devices nearly a quarter- . century earlier).

62. See Global-Tech Appliances, Inc. v. SEB S.A., 131 S. Ct. 2060, 2068 (2011) (according not only the "special force" of stare decisis to the construction in [Aro II], 377 U.S. 476, of the intent inquiry for contributory infringement under $\$ 271(\mathrm{c})$, but also adhering to the same logic in construing the analogous intent inquiry for induced infringement under $\$ 271(\mathrm{~b})$ ).

63. See Jason A. Rantanen, An Objective View of Fault in Patent Infringement, 60 Ам. U. L. REv. 1575, 1580 (2011).

64. See Siddharth Khanijou, Patent Inequity?: Rethinking the Application of Strict Liability to Patent Law in the Nanotechnology Era, 12 J. TECH. L. \& POL'Y 179, 183 (2007).

65. See Roger D. Blair \& Thomas F. Cotter, Strict Liability and Its Alternatives in Patent Law, 17 BERKELEY TECH. L.J. 799, 807-08 (2002).

66. See id. at 800-01 (distinguishing between being liable for infringement, for which the "strict liability" designation is acceptable, and recovering damages, for which the 35 U.S.C. $§ 287$ patent-marking statute requires notice of the patent); Khanijou, supra note 64, at 197 (accepting direct infringement as a strict liability offense for purposes of infringement liability while identifying, as Professors Roger Blair and Thomas Cotter do, a notice requirement for the recovery of damages); Rantanen, supra note 63, at 1590 (accepting direct infringement as a strict liability offense and focusing instead on willful, induced, and contributory infringement).

67. See 135 S. Ct. 1920 (2015).

68. Id. at 1924 . 
debate over direct infringement as well. ${ }^{69}$ The case marked the Court's third recent foray into the tort underpinnings of patent infringement doctrine.

The first was Global-Tech, in which the Court held that induced infringement under 35 U.S.C. $\$ 271$ (b) requires intent and knowledge not merely that the induced actions took place but also that the induced actions constituted infringement. ${ }^{70}$ The Court in Global-Tech drew a basic tort distinction between mental states regarding actions in the world and mental states regarding those actions' legal consequences. ${ }^{71}$ As the Court concluded, induced infringement requires both. ${ }^{72}$

The second was Limelight, in which the Court held that indirect infringement requires an underlying direct infringement. ${ }^{73}$ The dispute before the Court was the divided infringement of a method patent conducted at arm's length: Limelight had performed some steps, and other parties outside Limelight's control had performed the rest. ${ }^{74}$ The en banc Federal Circuit held Limelight liable for inducement by finding that while no one was liable for an underlying direct infringement, the requisite underlying infringement had taken place because all the steps had been performed. ${ }^{75}$ The Court rejected this notion of joint tortfeasance, explaining that if the actions that supposedly constitute direct infringement are not enough to create liability, then what has taken place is not direct infringement. ${ }^{76}$

In both cases, the Court analyzed the intent standard of induced infringement by comparing it to direct infringement, which produced helpful partial answers. Global-Tech properly distinguished between intent as to actions and intent as to the actions' legal implications. ${ }^{77}$ Limelight originally punted on that distinction as to direct infringement, though it did pose the issue helpfully through divided infringement: even if the actions of multiple parties when considered collectively would directly infringe a patent, why should their actions be considered collectively in the first place ${ }^{78}$ The question, though helpful, remained

69. Id. at 1926.

70. Global-Tech Appliances v. SEB S.A., 131 S. Ct. 2060, 2068 (2011).

71. Id. at 2065.

72. Id. at $2067-68$.

73. Limelight Networks, Inc. v. Akamai Techs., Inc., 134 S. Ct. 2111, 2115 (2014).

74. Id. at 2115-16.

75. Id. at 2116-17.

76. Id. at 2117-18.

77. See Global-Tech, $131 \mathrm{~S}$. Ct. at 2065 and text accompanying note 71 . On rehearing, an en banc Federal Circuit addressed this distinction. Akamai Techs., Inc. v. Limelight Networks, Inc., 797 F.3d 1020, 1023 (2015) (en banc) (per curiam).

78. Limelight, $134 \mathrm{~S}$. Ct. at $2117-18$. For a more detailed discussion of the proper role for tortious intent in divided patent infringement, see infra Section III.D. 
unanswered in Limelight $^{79}$

Prior to Commil, induced infringement required the following conditions: A patent must actually be directly infringed; the alleged inducer must know that it induced certain actions; and the alleged inducer must know that the actions that it induced constituted infringement of the patent. ${ }^{80}$ The question before the Court in Commil was whether the alleged inducer must also know that the patent was valid-whether a good-faith belief in the patent's invalidity is sufficient to defeat a claim of induced infringement. ${ }^{81}$ The Federal Circuit majority in Commil correctly observed that because direct infringement requires a patent to be valid, ${ }^{82}$ intent or knowledge that the patent is valid is relevant to the requisite intent or knowledge that the direct infringement took place. ${ }^{83}$ Put another way, just as one cannot infringe an invalid patent, someone who believes in good faith that a patent is invalid cannot intend for it to be infringed. ${ }^{84}$

Affirming the Federal Circuit's conclusion in Commil would, desirably, have identified even more clearly the tort law distinction: between mental states regarding (induced) actions and mental states regarding the legal implications of those actions. Yet, the Court in Commil ignored this distinction and said only that "infringement and validity are separate issues under the [Patent] Act," so knowledge or intent regarding one does not necessarily implicate knowledge or intent regarding the other. ${ }^{85}$

Moreover, the Court's opinion did not merely forgo an opportunity to clarify the confused view of tortious intent in patent infringement doctrine. It also echoed the Government's (supporting Commil)

79. The Supreme Court reversed the Federal Circuit's en banc opinion and remanded the case for further consistent proceedings, and the Federal Circuit reiterated its earlier conclusion that the facts of the case did not satisfy the governing standard for divided infringement (this time without its overturned inducement theory). On rehearing in the Federal Circuit, the court addressed infringement divided among different actors and found that entities can be responsible for others' performance in two instances: "(1) where that entity directs or controls others' performance, and (2) where the actors form a joint enterprise."

80. Petition for Writ of Certiorari at 8, Commil USA, LLC v. Cisco Sys., Inc., 720 F.3d 1361, 1368 (Fed. Cir. 2013) (No. 13-896), cert. granted, 135 S. Ct. 752 (2014), and vacated, 135 S. Ct. 1920 (2015).

81. Id. at i (seeking review on "[w]hether the Federal Circuit erred in holding that a defendant's belief that a patent is invalid is a defense to induced infringement under 35 U.S.C. $\S 271(\mathrm{~b}) ")$.

82. Commil, $720 \mathrm{~F} .3 \mathrm{~d}$ at 1368 (explaining that " $\mathrm{i}] \mathrm{t}$ is axiomatic that one cannot infringe an invalid patent").

83. Id.

84. See Brief of Professor Saurabh Vishnubhakat as Amicus Curiae in Support of Respondent at 2-3, Commil, 135 S. Ct. 1920 (No. 13-896).

85. Commil, $135 \mathrm{~S}$. Ct. at 1928. 
interpretation of the Court's own prior dicta that direct infringement, as a baseline matter, is a strict liability offense. ${ }^{86}$

Tracing this dicta backward from Commil provides some of the clearest provenance for the strict liability error in patent law. In Commil, the Court cited a footnote from Global-Tech, which states, "Direct infringement has long been understood to require no more than the unauthorized use of a patented invention. Thus, a direct infringer's knowledge or intent is irrelevant." ${ }^{\text {87 }}$ The footnote fails to support the strict liability conclusion. On its own terms, it does not specify what is irrelevant about the alleged direct infringer's mental state: knowledge or intent about its own actions, or knowledge or intent about the legal consequences of those actions.

In fact, both of the sources the Commil Court cited suggest only that knowledge or intent about legal consequences is irrelevant. ${ }^{88}$ The Court's 1964 opinion in Aro II only restated the text of $\S 271$ (a) that making, using, or selling the invention without authority is an infringement. ${ }^{89}$ Professor Walker and, later, Professor Anthony Deller explained that only direct infringement requires neither knowledge of the patent nor appreciation that one's act is infringement. ${ }^{90}$ These propositions, without more, do not amount to strict liability. If either treatise could plausibly have concluded that one can be a direct infringer even without intent to commit the relevant actions, for example, strict liability would have been a more defensible view.

Because the role of tortious intent in direct infringement was not before the Court in Commil, ${ }^{91}$ this passing reference to strict liability remains dicta, but it highlights the pervasiveness of the confusion that surrounds the infringement doctrine with respect to its tort underpinnings.

\section{What Strict Liability Really Means}

Looking to tort law itself is a useful way to compare what strict liability means as a conceptual matter to evaluate what it means in the borrowed sense that patent law has employed. At first blush, it may seem formalistic to distinguish between standards such as actual intent, recklessness, and willful blindness for determining willful infringement

86. Id. at 1926.

87. Global-Tech Appliances, Inc. v. SEB S.A., 131 S. Ct. 2060, 2065 n.2 (emphasis added) (citation omitted).

88. See Aro II, 377 U.S. at 484; 3 DELLER, supra note $30, \S 453$.

89. Aro II, 377 U.S. at 484.

90. See supra notes $29-30$ and accompanying text.

91. Commil, $135 \mathrm{~S}$. Ct. at 1926 (stating that the "precise issue to be addressed concerns a claim of improper inducement to infringe"). 
on one hand $\mathrm{d}^{92}$ and so-called strict liability for determining direct infringement on the other hand. Certainly, the Federal Circuit has a welldocumented reputation for formalism in its jurisprudence. ${ }^{93}$ It is also questionable whether tort law itself supports such distinctions. If not, then the best argument for distinguishing among levels of purposive action in various forms of patent infringement may be simply that patent jurisprudence requires some measure of formalism to minimize needless disruption to existing doctrine. Nevertheless, if tort law does plausibly support such distinctions, then the case is even stronger insofar as the debates in tort theory can offer greater transparency to the applied case of the tort of patent infringement.

In fact, categorical distinctions are not anathema to tort. Despite the general hostility in modern tort law toward formalism or conceptualism, ${ }^{94}$ early legal realist views of tort were more concerned with rejecting any single unifying theory of tort doctrine. ${ }^{95}$ In this project, realist tort scholars such as Professor Fleming James readily adopted categorical distinctions when it suited them. ${ }^{96}$ It was Professor James himself who: first differentiated intentional torts, negligent torts, and so-called strict liability torts to describe what he called the "heterogeneous mass of stuff" that was injury law. ${ }^{97}$

Tort law's own view of strict liability is mixed. The corrective justice strain of the tort literature increasingly questions whether strict liability even exists any longer as a doctrine that is analytically distinct from negligence. ${ }^{98}$ For example, in his unambiguously titled assessment, The Death of Strict Liability, Professor Peter Gerhart argued that strict

92. See supra notes 47-54 and accompanying text (discussing the requirements for willful infringement).

93. See Timothy R. Holbrook, The Supreme Court's Complicity in Federal Circuit Formalism, 20 SANTA Clara COMPUTER \& High TECH. L.J. 1, 1-2 (2003) (discussing the Federal Circuit's bias of articulating bright-line rules at the cost of fairness and the Supreme Court's recent decisions enabling this formalism agenda); Arti K. Rai, Engaging Facts and Policy: A Multiinstitutional Approach to Patent System Reform, 103 CoLUM. L. REv. 1035, 1103-10 (2003) [hereinafter Rai, Engaging Facts and Policy] (reviewing Federal Circuit formalism in the context of patent reform); John R. Thomas, Formalism at the Federal Circuit, 52 AM. U. L. REv. 771, 774 (2003) (exploring the recent trends in the Federal Circuit toward formalism and its potential for negatively impacting innovation policy).

94. See James R. Hackney, Jr., The Intellectual Origins of American Strict Products Liability: A Case Study in American Pragmatic Instrumentalism, 39 AM. J. LEGAL HIST. 443, 49091 (1995) (describing the "anti-formalist turn in American thought" that characterized the pragmatic development of strict liability).

95. Id. at 490 .

96. See Fleming James, Tort Law in Midstream: Its Challenge to the Judicial Process, 8 BUFF. L. REV. 315, 321 (1959).

97. Id. at 315 .

98. Peter M. Gerhart, The Death of Strict Liability, 56 BUFF. L. REv. 245, 271 (2008). 
liability was originally different from negligence in only one way. ${ }^{99}$ Negligence could penalize no more than failures to exercise due care, but reasonable care could still produce externalities that the law has a normative interest in mitigating. ${ }^{100}$ To cast the necessary wider net, socalled strict liability arose to evaluate not the quality of care, but the quality of the decision making related to the activity itself. ${ }^{101}$ Such decisions may pertain to a variety of traits associated with the activity, such as where or when it is done, how frequently, and by what method. ${ }^{102}$ In fact, these more finely grained evaluations of activity-based decisions are a subset of the general label of "abnormally dangerous" or "ultrahazardous" activities with which strict liability is traditionally identified. ${ }^{103}$ Importantly, however, evaluating activity-based decisions does not require wholly disregarding fault as in the customary understanding of strict liability. ${ }^{104}$

The upshot, according to Professor Gerhart, is that in trying to move beyond the inability of negligence to deter conduct that is reasonable as to due care but unreasonable in other ways, the notion of strict liability has been an overcompensation. On one hand, a fault-based view of unreasonable activity-based decisions can cast the wider net that strict liability purports to offer. In other words, the strict liability cases would, in the main, have turned out the same if the courts had more precisely evaluated the quality of the tortfeasor's activity-based decisions rather than claiming broadly to allocate liability without fault. ${ }^{105}$ On the other hand, activity-based decisions may also be reasonable as to place, time, frequency, method, etc., leaving a pure residual risk of the truly unavoidable accident — one that could take place even if one exercised due care and made entirely reasonable activity-based decisions. ${ }^{106}$ The strict liability cases have not imposed liability to the extent of these truly unavoidable accidents, where even activity-based decisions were

99. Id. at 251 (summarizing the difference between so-called strict liability and negligence). See generally Steven Shavell, Liability for Accidents, in 1 HANDBOOK OF LAW AND ECONOMICS (A. Mitchell Polinsky \& Steven Shavell, eds., 2007) (discussing a theoretical treatment of strict liability as an incentive system for reducing accident costs); Steven Shavell, Strict Liability Versus Negligence, 9 J. LEGAL STUD. 1 (1980) (comparing strict liability and negligence rules based on the incentives they provide).

100. Gerhart, supra note 98, at 251.

101. Id. at 251-53.

102. Id. at 247.

103. Id

104. Id. at $257-58$.

105. Id. at 297-306 (arguing that the outcomes of strict liability cases are actually applications of Gerhart's fault-based theory).

106. Id. at $254-55$. 
reasonable ${ }^{107}$ Indeed, the only way to force actors to internalize the pure residual risk of truly unavoidable accidents would be to turn to some purely distributive justice theory of tort where loss distribution entirely trumps individual agency, though the current body of tort law has largely remained with corrective justice. ${ }^{108}$

Historically, this distinction between activity-based risks that persist despite due care and residual risks that represent truly unavoidable accidents has been most salient in the context of products liability. ${ }^{109} \mathrm{In}$ that context, the philosophical arguments of pragmatism, the policy prescriptions of institutional economics, and the jurisprudential approach of legal realism ultimately led to a pair of seminal judicial decisions that articulated what the purpose and profile of strict liability would be. ${ }^{110}$

First was MacPherson v. Buick Motor Co. ${ }^{111}$ in which the purchaser of a car was injured when a defective wooden wheel in the car crumbled, causing the car to collapse. ${ }^{12}$ Though defendant Buick had not manufactured the wheel but merely installed it, Justice Benjamin Cardozo found liability "irrespective of [privity of] contract" because Buick had knowledge of a probable danger and had a duty to make its automobiles with care. ${ }^{113}$

The second was Escola v. Coca Cola Bottling Co. of Fresno, ${ }^{114}$ in which a restaurant waitress was injured when a bottle of Coca Cola spontaneously exploded in her hand, severing a number of blood vessels, nerves, and muscles in her thumb and palm. ${ }^{115}$ Though the court found defendant Coca Cola liable on a fault-based res ipsa loquitor theory of negligence, ${ }^{116}$ Justice Roger Traynor in a concurring opinion argued for what he called an "absolute liability" for manufacturers who place articles in commerce that prove injuriously defective. ${ }^{117}$ Less than twenty years later, the Escola concurrence prevailed in Greenman v. Yuba Power Products, Inc. ${ }^{118}$ with Justice Traynor writing for a unanimous court. ${ }^{119}$

107. Id. at 307 (accepting that "no-fault liability is theoretically possible" but that all cases of accidents, despite due care, were actually about unreasonable activity-based decisionmaking - and thus still about fault).

108. Id. at $248-49$.

109. See id. at $286-88$.

110. Hackney, supra note 94, at 489 (referring to "the landmark judicial opinions" implementing the theoretical legal realist case for strict liability).

111. 111 N.E. 1050 (N.Y. 1916).

112. Id. at 1051 .

113. Id. at 1053 .

114. 150 P.2d 436 (Cal. 1944).

115. Id. at 438 .

116. Id. at 440 .

117. Id. (Traynor, J., concurring).

118. 377 P.2d 897 (Cal. 1963).

119. Id. at 898 . 
These formative product liability cases suggest the uncertainly cabined nature of strict liability. In MacPherson, Justice Cardozo declined to divorce the defendant manufacturer's purposive actions from its liability, expressly requiring knowledge on the part of the manufacturer of a danger "not merely possible, but probable." 120 By comparison in Escola, Justice Traynor made an essentially distributive argument regarding a manufacturer's ability to internalize the cost to "reduce the hazards to life and health inherent in defective products." 121 However, he justified this allocation of risk on the grounds that the risk of injury or defect associated with manufacturing is "a constant risk and a general one," thus requiring a constant and general protection that the manufacturer is best positioned to provide. ${ }^{122}$ How constant and how general the risk may be are empirical questions, and the manufacturer can undoubtedly do much to mitigate that risk by internalizing the cost of changing its activity-based decisions. ${ }^{123}$ Yet expanding tort liability beyond failures of due care to failures of activity-based decisions is still a fault-based regime.

What remains unclear is whether this activity-based view of products liability fully realizes Justice Traynor's concerns in Escola, or whether products liability is so distributive as to capture pure residual risk akin, in Professor Gerhart's example, to requiring one person to be liable when lightning strikes another. ${ }^{124}$ The literature suggests that neither is fully true: fully distributive strict liability is the rule for manufacturing defects whereas a fault-based reasonableness standard is the rule for design defects and warning defects. ${ }^{125}$

From this debate within tort law itself of what strict liability comprises and of what corrective and distributive values strict liability promotes, patent law can gain much needed clarity about how to allocate the risks, costs, and losses associated with the tort of patent infringement. The instrumental goals and balances involved in patent infringement and related doctrines do not justify a fully distributive form of economic liability that is concerned only with spreading loss without regard to agency or purposive action. Therefore, the way tort law frames the concept of strict liability is not only a careless view of direct infringement, but also a normatively inappropriate one. An important

120. MacPherson v. Buick Motor Co., 111 N.E. 1050, 1051 (N.Y. 1916).

121. Escola, 150 P.2d at 440 (Traynor, J., concurring).

122. Id. at 441 .

123. See Gerhart, supra note 98 , at 247 (discussing the activity-based parameters of place, time, frequency, and method).

124. Id. at 311 .

125. See David G. Owen, Defectiveness Restated: Exploding the "Strict" Products Liability Myth, 1996 U. ILL. L. REV. 743, 744. 
result of this mistaken strict liability view is that the burden of avoiding infringement appears to fall entirely on the public's ability to understand precisely the boundaries of patent rights - entirely on the patent notice requirement.

\section{B. The Overburdened Notice Requirement}

Critiques and defenses of the U.S. patent system regard notice as an essential function and diverge largely on whether the current system adequately performs that function. ${ }^{126}$ The indeterminacy that results from inadequate notice is forceful evidence that the law does not warrant the exclusionary power of patents and that their assertion is an illegitimate restraint of economic activity. Notice itself is not a unitary principle but rather a shorthand for two related requirements of the patent systemone prescriptive and the other descriptive. These forms of notice, in turn, call for precision and accuracy to be effective. For evaluating the impact of a strict liability view on direct infringement, it is precision in prescriptive notice that is of greatest importance.

\section{Two Metaphors of Patent Notice}

Prescriptive notice, or boundary notice about the scope of a patent's claims, is what most discussions of the patent system mean by the term "notice" in advocacy, ${ }^{127}$ adjudication, ${ }^{128}$ and academic discourse. ${ }^{129}$ Descriptive notice, or notice about the nature of the invention and how to practice it, is more commonly understood as the teaching function of

126. Compare, e.g., James BesSEn \& Michael J. Meurer, Patent Failure: How Judges, BUREAUCRATS, AND LAWYERS PUT INNOVATORS AT Risk 46-72 (2009) (arguing that patents currently provide inadequate notice as to their boundaries and therefore do not merit their broad property-like rights to enjoin others), with David J. Kappos, Investing in America's Future Through Innovation: How the Debate over the Smart Phone Patent Wars (Re)Raises Issues at the Foundation of Long-Term Incentive Systems, 16 STAN. TECH. L. REV. 485, 494-97 (2013) (arguing that ongoing administrative reforms in patent examination together with recent Federal Circuit case law and industry best practices have improved the clarity and correspondence between what patents disclose and what they claim, largely fulfilling the notice function).

127. See, e.g., Defendant-Appellee's Response to Plaintiff-Appellant's Opening En Banc Brief at 40, McKesson Techs. Inc. v. Epic Sys. Corp., No. 2010-1291 (Fed. Cir. Aug. 8, 2011), 2011 WL 3796780 (citing Ariad Pharm., Inc. v. Eli Lilly and Co., 598 F.3d 1336, 1347, 1364 (Fed. Cir. 2011) (describing the function of the patent system's public notice function as providing "notice of the boundaries of the right to exclude").

128. See, e.g., Invitrogen Corp. v. Clontech Labs., Inc., 429 F.3d 1052, 1070 (2005) (referring to notice as information about the "enforceable boundary of the commercial patent right").

129. See, e.g., Dan L. Burk \& Mark A. Lemley, Fence Posts or Sign Posts? Rethinking Patent Claim Construction?, 157 U. PA. L. Rev. 1743, 1745-46 (2009) (describing the notice function of patents as "setting out clear boundaries to warn the public of what is and is not claimed"). 
patents. ${ }^{130}$ Thus, the institutional design of the patent system must resolve two subjects of indeterminacy: (1) the boundary notice function of delineating ex ante the scope of the exclusionary rights that a patent confers and (2) the teaching function of describing and enabling the practice of the patented invention.

Debate over the operation and fulfillment of the boundary notice and teaching functions has relied much on metaphors of trespass and contract, respectively. ${ }^{131}$ The boundary notice function reflects a need for clear, discernible limits so that others may avoid trespassing on the patentee's rights similar to how physical fences guard against unauthorized entry on real property. ${ }^{132}$ The teaching function reflects a bargained-for exchange between an inventor and society where the inventor conveys a descriptive and enabling disclosure about her invention while in return society conveys a limited right for the inventor to exclude others from practicing it. ${ }^{133}$ Both metaphors resonate strongly in American culture-the trespass metaphor with the importance of private property ${ }^{134}$ and the contract metaphor with the importance of agreement as an exercise of autonomy. ${ }^{135}$ In this conception, moreover, the contract must precede the trespass because the bargain between inventor and society is what legitimates the inventor's property-like right against the encroachment of others' practice of her invention. If a patent does not give adequate notice about its boundaries, then the inventor has not kept her end of the patent bargain, and her exclusionary assertion of the patent is no longer a protection of her own rights against encroachment but is rather an illegitimate encroachment on the rights of others. Thus, the patent holder's argument from trespass is in tension with the alleged

130. See Univ. of Rochester v. G.D. Searle \& Co., Inc., 358 F.3d 916, 922 n.5 (2004) (distinguishing notice about what the invention is and how to practice it from notice about the boundaries of what the patent allows one to exclude others from doing).

131. Saurabh Vishnubhakat, Cognitive Economy and the Trespass Fallacy: A Response to Professor Mossoff, 65 FLA. L. REv. F. 38, 38-39 (2014).

132. E.g., Voda v. Cordis Corp., 476 F.3d 887, 900 (Fed. Cir. 2007) (referring to the violation of a patent right as a "trespass"). See generally Adam Mossoff, The Trespass Fallacy in Patent Law, 65 FLA. L. REV. 1687, 1692-94 (describing the history of the trespass metaphor in patent law).

133. See, e.g., Pfaff v. Wells Elecs., Inc., 525 U.S. 55, 63 (1998) (describing the patent system as "a carefully crafted bargain"); Kewanee Oil Co. v. Bicron Corp., 416 U.S. 470, 484 (1973) (describing disclosure as "the quid pro quo of the right to exclude"). The Supreme Court has further noted that the metaphor of bargained-for exchange is particular to patents. See Eldred v. Ashcroft, 537 U.S. 186, 216 (2003) (stating that "our references to a quid pro quo typically appear in the patent context").

134. David Fagundes, Property Rhetoric and the Public Domain, 94 MinN. L. Rev. 652, 677 (2010).

135. Tal Kastner, The Persisting Ideal of Agreement in an Age of Boilerplate, 35 L. \& SoC. INQUIRY 793, 796-97 (2010). 
infringer's -indeed, society's-argument from contract.

The practical effect of this tension on direct infringement is that the delineation of clear boundaries in the patent right is the more important aspect of patent notice, as the boundaries of the patent are what define whether infringement has taken place at all. The patent bargain, for its part, is presumed to be fulfilled because the law itself presumes that an issued patent is valid. ${ }^{136}$ Moreover, in a regime widely believed to impose strict liability for direct infringement, without regard to prior knowledge of the patent or intent to commit infringement, proper boundary notice bears the heavy burden of legitimating the exclusionary power of patents against the public. As the ongoing debate over ex ante notice of claim scope shows, that burden as currently understood is likely an unbearable one.

\section{Notice of Claim Scope}

Because the boundaries of patent rights reside in the claims of a patent, ${ }^{137}$ evaluating boundary notice is an exercise in construing patent claims. ${ }^{138}$ Claims that do not lend themselves to ex ante construction ${ }^{139}$ : reflect poor boundary notice, ${ }^{140}$ a problem that is particularly acute where it requires expensive litigation to adjudicate the boundary of the patent right. ${ }^{141}$ To be sure, the mere fact that litigation has taken place is not conclusive of notice failure nor even necessarily of uncertainty more

136. 35 U.S.C. $§ 282$ (2012). The party asserting invalidity bears the burden of overcoming the presumption by clear and convincing evidence, even when offering evidence not before the U.S. Patent and Trademark Office (USPTO) during examination. See Microsoft Corp. v. i4i Ltd. P'ship, 131 S. Ct. 2238, 2245-50 (2011).

137. Lighting Ballast Control LLC v. Philips Elecs. N. Am. Corp., 744 F.3d 1272, 1280-84 (Fed. Cir. 2014) (en banc) (observing that a patent claim "sets the boundaries of an exclusionary right good against the world at large"), vacated and remanded, 135 S. Ct. 1173 (2015) (remanding for reconsideration in light of Teva Pharmaceuticals USA, Inc. v. Sandoz, Inc., 135 S. Ct. 831 (2015)).

138. Trading Techs. Int'l, Inc. v. Open E Cry, LLC, 728 F.3d 1309, 1319 (Fed. Cir. 2013).

139. The amenability of patent claims to being construed is the patent "definiteness" requirement of 35 U.S.C. $\$ 112$ (b). In recent years, the standard for definiteness had been that a claim, read in view of the specification and prosecution history, was indefinite only if it was "insolubly ambiguous, and no narrowing construction" could "properly be adopted." Exxon Research \& Eng'g Co. v. United States, 265 F.3d 1371, 1375 (Fed. Cir. 2001). The Supreme Court very recently rejected this "insolubly ambiguous" standard and held that for a claim to be definite, it must "inform those skilled in the art about the scope of the invention with reasonable certainty." Nautilus, Inc. v. Biosig Instruments, Inc., 134 S. Ct. 2120, 2129-30 (2014).

140. See Harry Surden, Efficient Uncertainty in Patent Interpretation, 68 WASH. \& LEE L. REV. 1737, 1772-74 (2011) (relating the susceptibility of patent claims to unique, or at least manageable, determination with the sufficiency of notice provided by the patent).

141. Peter S. Menell \& Michael J. Meurer, Notice Failure and Notice Externalities, $5 \mathrm{~J}$. LEGAL ANALYSIS 1, 5, 10 (2013). 
generally. Patent litigation proceeds for a variety of reasons, including high value in the invention ${ }^{142}$ and economic calculations favoring efficient infringement, ${ }^{143}$ as well as uncertainty about whether the patent is valid or infringed. ${ }^{144}$ Nevertheless, where so-called "fuzzy boundaries"145 result in patent scope that is de facto broad, ${ }^{146}$ and where the exclusionary right is strong and property-like-stronger, in fact, if strict liability is the rule-the increased risk of infringement can aggravate the externalities that strategic litigation generates. ${ }^{147}$

Framing boundary notice with respect to consistency in claim construction is only one of two tasks in generating certainty about the

142. See generally John R. Allison et al., Valuable Patents, 92 GEO. L.J. 435, 439-40 (2004) (discussing the relationships among the value of inventions, the value of patents, and the assertion of patents in litigation to appropriate value).

143. See Ted Sichelman, Purging Patent Law of "Private Law" Remedies, 92 TEX. L. REv. $517,557-58$ (arguing that substantial disagreement over patent validity and scope coupled with high transaction costs in ex ante license negotiation may make infringement the economically efficient choice). Professor Ted Sichelman compares this to efficient breach in contract theory. Id. (citing Richard A. Posner, ECONOMIC ANALYSIS OF LAW 119-21 (7th ed. 2007)).

144. See Jay Pil Choi, Patent Litigation as an Informational-Transmission Mechanism, 88 AM. ECON. REV. 1249, 1250 (1998) (framing the dynamics of market entry as an externality of patent validity information revealed in litigation). See generally Alan C. Marco \& Saurabh Vishnubhakat, Certain Patents, 16 YALE J.L. \& TECH. 103 (2013) (surveying the sources and implications of uncertainty about the validity and infringement of patents, and estimating the market value of resolving that uncertainty through adjudicative litigation).

145. Professor Michael Meurer has helped popularize this term in the debate over patent notice. See, e.g., BESSEN \& MEURER, supra note 126, at 61, 70; Menell \& Meurer, supra note 141, at 12; Michael J. Meurer, Patent Examination Priorities, 51 WM. \& MARY L. REV. 675, 701-03 (2009).

146. See Damon C. Andrews, Why Patentees Litigate, 12 Colum. SCI. \& TECH. L. Rev. 219, 245 -46 (2011); see also Jay P. Kesan \& Andres A. Gallo, Why "Bad" Patents Survive in the Market and How Should We Change?-The Private and Social Costs of Patents, 55 EMORY L.J. $61,63,68-69,70,77-95$ (2006) (using a game-theoretic model to compare quantitatively the litigation costs and risks as between plaintiff and defendant, and finding that even demonstrably invalid patents can survive in the market as a result). Uncertainty in boundaries results in effectively broad boundaries due to risk aversion about the outcomes of patent litigation. See generally Andrews, supra, at 219 (arguing that the cost and risk of patent litigation have diminished the value of traditional remedies such as damages and injunctions, leaving patentees to plan deliberately around a likely up-front settlement).

147. Ted Sichelman, Commercializing Patents, 62 Stan. L. Rev. 341, 384 (2010) (arguing that such litigation "mak[es] the damage award or injunction value to the patentee inefficiently high relative to the social value of commercialization"); see also Mark A. Lemley \& Carl Shapiro, Patent Holdup and Royalty Stacking, 85 TEX. L. REV. 1991, 2009-10 (2007) (arguing that where a patent owner has the ability and legal right "to capture value that has nothing to do with its invention," the threat of litigation that it can exert results in economically inefficient disincentives for innovation by others, allegedly infringing firms that have often already sunk significant investments into research and development themselves). 
scope of patent rights, ${ }^{148}$ but it is the more important task. Accordingly, the Federal Circuit in Lighting Ballast Control v. Philips Electronics ${ }^{149}$ endorsed the importance of consistent claim construction for providing what the court called "horizontal certainty," which is of great importance to the market. ${ }^{150}$ Supplying this interpretive uniformity through de novo appellate review of claim construction may create "vertical uncertainty" about the outcomes of individual patent litigations, though the Lighting Ballast court appears to have accepted amicus representations that such vertical uncertainty costs are minimal. ${ }^{151}$ In practice, greater horizontal certainty means that a patent claim will mean the same thing in one district court as in subsequent district courts that construe the same claim. Greater vertical certainty means that a patent claim will turn out to mean the same thing in the appellate court as in the trial court below, usually due to a deferential standard of appellate review. Yet horizontal and vertical certainty are often in tension with each other.

For example, high horizontal certainty would likely coincide with low vertical certainty because de novo review of the claim construction would : create actual appellate precedent that consistently binds subsequent trial courts. Conversely, high vertical certainty would likely coincide with low horizontal certainty because deferential appellate review can inherently tolerate multiple inconsistent district court claim constructions. District courts might accept as persuasive the prior construction of another district court, but this is neither necessary nor certain. Moreover, horizontal. certainty concerning how the market understands a given patent claim corresponds to precise boundary notice, and vertical certainty about how a given patent claim fares in a particular litigation corresponds with accurate boundary notice. ${ }^{152}$ Of these, precision in boundary notice would seem to be the greater economic and systemic value, corresponding as it does to greater ex ante certainty around which to make

148. The other task is accuracy as to what the patent actually covers. If the supposed scope of patent rights is inaccurate (usually inaccurately broad), then the patent is invalid because the patentee has not fulfilled her end of the patent bargain. See supra notes 133-36 and accompanying text.

149. 744 F.3d 1272 (Fed. Cir. 2014) (en banc), vacated and remanded, 135 S. Ct. 1173 (2015).

150. Id. at 1287-88 (citing Brief of Amici Curiae Cisco Systems, Inc., Dell Inc., EMC Corporation, Intel Corporation, SAP America, Inc., and SAS Institute Inc. in Support of Neither Party at 19, Lighting Ballast, 744 F.3d 1272 (No. 2012-1014)).

151. Id. at $1288-89$.

152. Cf. Oskar Liivak, Rescuing the Invention from the Cult of the Claim, 42 SETON HALL L. REV. 1, 42 (2012) (characterizing patent claims as proxies for the inventions they protect). Professor Oskar Liivak cogently explains that the requirement against claim indefinitenesscorresponding here to the boundary notice function-ensures that claims are precise proxies for the invention, and the requirements for adequate disclosure in patents-corresponding here to the teaching function-ensure that the claims are accurate proxies. 
investments, conduct research and development, and commercialize inventions. As a practical matter, however, it is an open empirical question whether the valuable certainty of precision merits the costly pursuit of accuracy. ${ }^{153}$ Further compounding the complexity of the empirical question, trial courts may themselves give deference to administrative findings by the U.S. Patent and Trademark Office (USPTO) determinations of claim scope, an institutional relationship that is increasingly salient in view of the administrative post-grant patent reviews that the 2011 America Invents Act has created. ${ }^{154}$

In grappling with this tension, fostering greater precision in the boundary notice of patent claims has commanded significant attention in both the literature and governmental efforts at reform, particularly in the twenty years since the Supreme Court's decision in Markman v. Westview Instruments. ${ }^{155}$ The Markman decision explained that patent claim construction is a "mongrel practice" combining legal and factual determinations, ${ }^{156}$ and the decision has since given rise to the ubiquitous and contentious Markman proceedings early in patent lawsuits. ${ }^{157}$

In the literature, notable recent proposals to improve boundary notice include the development or greater use of technical dictionaries and USPTO-wide or examination art unit-wide glossaries to reduce the information costs that patent examiners must incur in evaluating applications for patent. ${ }^{158}$ Given the widely noted connection between

153. This was a point that Judge Kathleen O'Malley's dissent made in Lighting Ballast: the horizontal certainty purportedly offered by consistent claim construction through de novo appellate review requires finality (i.e., vertical certainty) in individual judgments. As a result, she argued, Lighting Ballast and its affirmation of Cybor Corp. v. FAS Techs., Inc., 138 F.3d 1448 (Fed. Cir. 1998) (en banc), tend to undercut certainty, discourage settlement, and foster litigation through the final appeal. Lighting Ballast, 744 F.3d at 1296, 1310 (O'Malley, J., dissenting).

154. For the seminal discussion of the institutional dimensions of deference as between courts and as between the Judiciary and the Executive on the questions of patent claim scope and uniformity, see generally Rai, Engaging Facts and Policy, supra note 93, at 1086-1101.

155. 517 U.S. 370 (1996).

156. Id. at 377-78.

157. Though Markman itself does not require a particular timing for claim construction within the life cycle of patent litigation, courts have settled on a practice of construing claims after at least some fact discovery but still early enough to promote settlement in view of the issued claim construction ruling. See RebeCCA N. EYRE, JoE S. CECLL \& ERIC TOPOR, FeD. JUD. CTR., Patent Claim Construction: A Survey of Federal District Court Judges 16-17 (Feb. 2008), www.fjc.gov/public/pdf.nsf/lookup/patclaim.pdf/\$file/patclaim.pdf. The practice of premising claim construction on fact discovery is appropriate given the regularity with which courts "benefit from explanation of the technology and the instruction of treatises" and from "experts in the science or technology ... in understanding the meaning and usage of a claim term." Lighting Ballast, 744 F.3d at 1284-85.

158. See, e.g., Lee Petherbridge, Positive Examination, 46 IDEA: INTELL. ProP. L. REV. 173 , $198(2006)$. 
boundary notice problems and patents on software-related inventions, ${ }^{159}$ academic proposals have also focused on issues that are particularly important to software patent litigation, such as functional claiming, ${ }^{160}$ and on reforms that can disproportionately improve the quality of software patents, such as the USPTO's new post-grant review powers under the America Invents Act. ${ }^{161}$ Notably, some of the most prominent of these discussions expressly stop short of abolishing software patents altogether and argue persuasively against industry-specific rules for patent protection. ${ }^{162}$

Likewise in government, the White House Task Force on High-Tech Patent Issues recently directed an executive action toward "tightening functional claiming" in patents ${ }^{163}$ through, inter alia, the use of claim glossaries in the specifications of applications for patent. ${ }^{164}$ The 2011

159. See, e.g., James Bessen \& Michael J. Meurer, The Direct Costs From NPE Disputes, 99 CoRnell L. Rev. 387, 391-94 (2014); Arti K. Rai, Improving (Software) Patent Quality Through the Administrative Process, 51 Hous. L. Rev. 503, 504-05 (2013) [hereinafter Rai, Improving (Software) Patent Quality].

160. See, e.g., Kevin Emerson Collins, Patent Law's Functionality Malfunction and the Problem of Overbroad, Functional Software Patents, 90 WASH. U. L. REV. 1399, 1427-30 (2013); Mark A. Lemley, Software Patents and the Return of Functional Claiming, 2013 WIS. L. REv. 905,907 (2013) (noting that lawyers have a tendency to broaden claims as much as possible to acquire the strongest rights for their clients).

161. See, e.g., Rai, Improving (Software) Patent Quality, supra note 159, at 533-39.

162. E.g., Dan L. Burk \& Mark A. Lemley, The Patent Crisis and How the Courts Can SOLVE IT 157-58 (2009); ADAM B. JAFFE \& JOSH LERNER, INNOVATION AND ITS DISCONTENTS: How Our Broken Patent System Is Endangering InNovation and Progress, and What to Do ABOUT IT 198 (2004); Michael Risch, Everything Is Patentable, 75 TENN. L. REv. 591, 622 (2008). But see Pamela Samuelson, Benson Revisited: The Case Against Patent Protection for Algorithms and Other Computer Program-Related Inventions, 39 EMORY L.J. 1025, 1029-30 (1990); Joshua D. Sarnoff, Patent-Eligible Inventions After Bilski: History and Theory, 63 HASTINGS L.J. 53, 110 (2011).

163. See The White House: Office of the Press Sec'y, FACT SHEet: White House TASK FORCE ON HIGH-TECH PATENT ISSUES (2013), https://www.whitehouse.gov/the-pressoffice/2013/06/04/fact-sheet-white-house-task-force-high-tech-patent-issues.

164. See generally Glossary Initiative, U.S. PATENT \& TRADEMARK OfFICE, http://www.uspto.gov/patent/initiatives/glossary-initiative (last visited Apr. 24, 2016) (providing an overview of Glossary Initiative, a claim clarity training program). In fact, the USPTO's exploration of requiring applicant glossaries predates the June 2013 White House announcement and has been part of a policy agenda directed toward patent quality more generally. See Request for Comments on Preparation of Patent Applications, 78 Fed. Reg. 2960-61 (Jan. 15, 2013). The response to these proposals, including the claim glossary requirement, has been mixed. Compare Suzanne Michel, Michael Meehan \& William G. Jenks, U.S. Patent \& Trademark Office, COMMENTS OF GOOGLE INC. 7 (2013), http://www.uspto.gov/patents/init_events/ swglossary_e_google_2013oct23.pdf (supporting glossary usage as a source of efficiency and improved claim clarity), and Charles DuAn, Julie SAMUels \& Daniel NAZER, U.S. PATENT \& Trademark Office, Comments of Public Knowledge and the Electronic Frontier FOUNDATION 2 (2013), http://www.uspto.gov/patents/init_events/swglossary_a_eff_ 
report of the Federal Trade Commission on aligning patent notice with competition policy also identified boundary notice difficulties rooted in functional claiming and other causes, such as variation of technical nomenclature and the patent system's institutional preference for deferring the resolution of ambiguity in patent rights. ${ }^{165}$

The vigor and scope of these debates and proposals reflect the high stakes of failure in boundary notice and emphasize the policy challenge that patent law must resolve if direct infringement continues to be mistakenly regarded as a strict liability offense whose principal justification resides in providing adequate notice to the public about the boundaries of patent rights. Conversely, a doctrine of direct infringement that properly accounts for the tortious intent of alleged infringers can offer both powerful new solutions to the current patent policy debate and a theoretical underpinning for existing proposals that are thus far pragmatic departures from the legal theory of patent infringement.

\section{AN INTENTIONAL TORT THEORY OF INFRINGEMENT}

The thrust of Part I has been that the law of direct patent infringement is incorrect to conclude that disregarding any knowledge of a patent or any intent to infringe the patent is synonymous with strict liability, as this conclusion ignores an additional necessary inquiry: whether the alleged infringer intended to perform an act that constitutes infringement. Part II argues that the direct infringement doctrine should expressly inquire into this tortious intent and that such an inquiry follows from well-understood tort principles that connect purposive action to liability in tort.

\section{A. Tort and the Exercise of Agency}

The exercise of agency through purposive action has increasingly become an explicitly theorized basis for the corrective justice that tort offers. In brief, the argument from purposive action in justifying tort liability regards the exercise of agency as a necessary condition, ${ }^{166}$ or at

2013oct24.pdf (same), with E-mail from Manny W. Schecter, Chief Patent Counsel for IBM Corp., \& Alison D. Mortinger, Counsel of Strategy and Policy for IBM Corp., to SoftwareRoundtable2013@uspto.gov (Oct. 3, 2013), http://www.uspto.gov/patents/init_events/ swglossary_e_ibm_2013oct03.pdf (expressing skepticism about glossary usage due to burdens of time and cost as well as the potential for downstream narrowing effects on claims), and Letter from Robert R. Sachs to Janet Gongola, Patent Reform Coordinator, U. S. Patent \& Trademark Office (Nov. 1, 2013), http://www.uspto.gov/patents/init_events/swglossary_f_sachs_2013 nov01.pdf (critiquing, inter alia, the potential in glossary usage for additional strategic behavior in patent prosecution).

165. See Fed. Trade Comm'n, The Evolving IP MarketPlace: Aligning Patent Notice AND REMEDIES WITH COMPETITION 80-86 (2011).

166. See Jules L. Coleman, The Practice of Corrective Justice, 37 ARIZ. L. REv. 15, 26 (1995) (arguing that "the claims of corrective justice arise only with respect to losses occasioned 
least a normatively appropriate one ${ }^{167}$ to ensure that tort law adequately "secures favorable conditions for the exercise of our rational agency." 168 These themes are apparent in the roles that intent and the appreciation of consequences have implicitly played in the historical development of tort law.

\section{A Brief History of Tort}

Tort originated in two common law writs: the writ for the action of trespass and the writ for the action of trespass on the case. ${ }^{169}$ The two causes of action distinguished between forcible and direct injury (trespass) and indirect and consequential injury (case). ${ }^{170}$ Trespass came first, ${ }^{171}$ and its emphasis on forcible and direct injury reflects the criminal law origin of the action for trespass, which emerged to remedy actions "done by force and arms against the king's peace." 172

Though the writs for trespass and case focused on direct versus indirect causation of the plaintiff's injury rather than on the defendant's intent, intent was nevertheless important to the development of trespass and case as actions in tort. For example, the existing action of novel disseisin had been available when an intrusion onto land led to one's

by human agency" notwithstanding specific disagreements about the relevant limitations, conditions, or importance of such agency); John C.P. Goldberg, The Constitutional Status of Tort Law: Due Process and the Right to a Law for the Redress of Wrongs, 115 YALE L.J. 524, 609 (2005) (observing that "tort law, by articulating and enforcing relational duties, treats actors as agents who are responsible to others for the consequences of their actions").

167. See Tony Honoré, Responsibility and Luck, 104 L.Q. REV. 530, 531, 539-41 (1988) (advancing an "outcome-responsibility" argument that choosing is a necessary act of agency, that exercising agency requires accepting the consequences of choices, and that normatively allocating liability for consequences is respectful of human agency).

168. Gregory C. Keating, Strict Liability and the Mitigation of Moral Luck, 2 J. ETHICs \& SOC. PHIL. 1, 11 (2006).

169. See John W. Salmond, The law of Torts: a Treatise on the English law of LIABILITY FOR CIVIL INJURIES 155 (2d ed. 1907). These actions came to be known simply as "trespass" and "case," respectively.

170. See id. at 155-57. This conceptual focus on degrees of causation was altogether different from the later interest in the existence and degree of the tortfeasor's intentions. $I d$. at 157.

171. See 3 Thomas AtKins Street, The Foundations of Legal liabllity: A PResentation of THE THEORY AND DEVELOPMENT OF THE COMMON LAW 248-51 (1906) (tracing the emergence of trespass on the case from the earlier action for trespass through Parliament's exercise of the 1285 Statute of Westminster II, which granted it the right to issue new writs and thereby create new legal rights in the King's common law courts).

172. Id. at $229-30$. 
dispossession of the land ${ }^{173}$ or even to quiet enjoyment of it. ${ }^{174}$ The action required a competing claim of interest beyond mere intrusion, and making this distinction was an inquiry into the alleged wrongdoer's intent. ${ }^{175}$ Such intent-based bifurcations also existed between criminal larceny and civil recovery of chattels, and between criminal felonious assault and minor civil batteries. ${ }^{176}$

Once established, the writs for trespass and case only gradually shifted from a distinction of causal sequence to the modern distinction between conduct that is intentional and conduct that reflects a lower degree of purposive action, such as a negligent omissions. ${ }^{177}$ The shift, moreover, was not a one-to-one correspondence: a writ of trespass could lie even for negligent injuries so long as they were direct, whereas indirect injuries required an action on the case even if the injuries were intentionally inflicted. ${ }^{178}$ Regardless, from its earliest days, tort law has recognized in one way or another differentiable levels of intent reflecting purposive actions behind alleged bad acts and has translated those differences into legal distinctions.

\section{Gradations of Tortious Intent}

The transition to modern intent-based tort law increasingly recognized two important principles. First, pure accident should generally not form the basis of liability, and at least some wrongful intent or some failure to exercise due care should be necessary. ${ }^{179}$ Second, the degree of liability imposed should be commensurate with the alleged wrongdoer's degree of purposive action and her appreciation of the consequences of that action. ${ }^{180}$ Thus, liability ought to be mildest for conduct that is inadvertent (though still negligent by the relevant standard of care), harsher for conduct that disregards likely effects, harsher still for conduct that is intentional but without malice, and harshest for conduct that is maliciously intentional. ${ }^{181}$

The importance of purposive action and appreciation of consequences is further evident in modern tort law's definition of intent itself, which is acting to accomplish a result or believing that the result was substantially

173. See 2 Frederick Pollock \& Frederic W. Maitland, THe History of ENGLish LaW: BEFORE THE TIME OF EDWARD I, at 38 ( $2 \mathrm{~d}$ ed. 1899).

174. See id. at 34-36 (discussing the medieval concept of "seisin" both as possession and enjoyment protected by the action for disseisin, or dispossession).

175. See STREET, supra note 171, at 227.

176. See id. at 240-44.

177. See William L. Prosser, HandBooK of the LaW of Torts 36-38 (1941).

178. See, e.g., Leame v. Bray, (1803) 102 Eng. Rep. 724, 724-28 (K.B.), 3 East 593-96.

179. See PROSSER, supra note 177 , at 39 .

180. See id. at 39-40.

181. Id. 
certain to follow. ${ }^{182}$ Intent, thus defined, informs all torts that require high purposive action and appreciation of consequences, including invasions of personhood such as battery, ${ }^{183}$ assault,${ }^{184}$ and false imprisonment, ${ }^{185}$ as well as invasions of personal property such as trespass to chattels ${ }^{186}$ and conversion. ${ }^{187}$ This definition of intent also informs trespass to land, ${ }^{188}$ the tort most often analogized to patent infringement. ${ }^{189}$

\section{The Instructive Case of Trespass to Land}

Canonically, every form of trespass to land requires some level of intent. Unauthorized entry with intent creates liability even if the possessor of the land suffers no harm. ${ }^{190}$ Accordingly, mistake is no defense, and with one exception, even a reasonable contrary belief of law or fact does not excuse liability. ${ }^{191}$ Entry based upon a lower level of intent, such as reckless or negligent conduct, creates liability if it causes the possessor of the land a recognized harm. ${ }^{192}$ Likewise, an entry that is unintentional and non-negligent does not create liability even if it harms the possessor. ${ }^{193}$

It is worth examining whether this common law framework reflects a normative principle that a given level of intent is necessary to justify a given level of liability, or merely that a given level of intent is sufficient to justify a given level of liability. If these different levels of intent are necessary to justify their respective levels of land trespass liability, then the most stringent liability, one imposed without regard to harm, may

182. Compare RESTATEMENT (SECOND) OF TORTS § 8A (AM. LAw InST. 1965) ("The word 'intent' is used throughout the Restatement of this subject to denote that the actor desires to cause consequences of his act, or that he believes that the consequences are substantially certain to result from it."), with PROSSER, supra note 177, at 40 ("A person intends a result when he acts for the purpose of accomplishing it, or believes that the result is substantially certain to follow from his act.").

183. Restatement (SECOND) OF TORTS $\$ \$ 13,18$.

184. Id. $\$ \$ 21-34$.

185. Id. $\$ \S 35-38,40,43-45$.

186. Id. $\$ \$ 216-218,221-222$.

187. Id. $\$ \$ 222 \mathrm{~A}-224,226-227,229-231,233,237$.

188. Id. $\$ 158$.

189. See supra Subsection I.B.1 (discussing the trespass metaphor of patent infringement). See generally Mossoff, supra note 132 (critiquing on theoretical and empirical grounds the comparison of trespass to land with all encroachments upon the patent right).

190. RESTATEMENT (SECOND) OF TORTS $\$ 158$.

191. Id. \$164. A mistake of law or fact may excuse liability when the conduct of the possessor induces such a mistake. $I d . \S 164 \mathrm{cmt}$. b.

192. Id. $\$ 165$. Liability under this principle also arises where the intruder is engaged in an abnormally dangerous activity. $I d$.

193. Id. $\$ 166$. This exemption from liability does not apply where the intruder is engaged in an abnormally dangerous activity. $l d$. 
arise only from an intentional trespass to land; negligence or even recklessness will not do. Likewise, trespass that is both unintentional and accidental cannot support liability even where harm has occurred; recklessness or at least negligence is necessary. Conversely, if these different levels of intent are merely sufficient but not necessary to justify corresponding levels of liability, then diminished intent or even an absence of intent may support liability.

The principles of common law trespass to land refute the latter view. Absence of intent cannot support any liability for trespass to land. ${ }^{194}$ Put another way, trespass to land is not a strict liability tort. Moreover, diminished intent such as recklessness or negligence cannot support liability without regard to harm. ${ }^{195}$ For trespass to land, therefore, the different levels of intent are not merely sufficient but necessary to justify a commensurate level of liability. In fact, as Professor William Prosser identifies, this commensurability principle largely holds for torts in general. $^{196}$

Importantly, the relevant inquiry for trespass to land at each level on this commensurability scale is neither whether there was an intent to violate the possessor's rights nor whether there was even any knowledge that such rights exist, but simply whether there was an intent to perform the intrusive act: entering the land. ${ }^{197}$ So also for direct patent infringement, the tortious intent is to perform the infringing act: making, selling, or using the patented invention.

The analogy between trespass to land and patent infringement has long persisted in the law as a descriptive matter, ${ }^{198}$ but the normative relevance of trespass to the patent system is an issue of ongoing debate. So although tort law's principle of commensurability, between liability for the tort and the level of purposive intent animating the tort, is not limited to trespass, the prevalent application of trespass to patent infringement warrants discussion about the continuing suitability of this analogy.

Even Professors James Bessen and Michael Meurer implicitly accept, in their critique of patents for providing less clear notice than the real

194. See supra notes $190-93$ and accompanying text.

195. Id.

196. Professor Prosser stated the principle quite broadly that "regardless of the form of the action, there should be no liability for pure accident." PrOSSER, supra note 177, at 39 .

197. RestaTEMENT (SECOND) OF TORTS $\$ 164 \mathrm{cmt}$. a.

198. Corning Glass Works v. Sumitomo Elec. U.S.A., Inc., 868 F.2d 1251, 1257 (Fed. Cir. 1989) (explaining in the language of real property surveying that a patent claim "provides the metes and bounds of the right which the patent confers"); Hovey v. Henry, 12 F. Cas. 603, 604 (C.C.D. Mass. 1846) (No. 6,742) (comparing an inventor to a farmer by stating that the inventor "holds a property in his invention by as good a title as the farmer holds his farm and flock"); see supra note 132 and accompanying text. 
property trespass system would tolerate, that trespass doctrine is quite relevant to patent infringement. Their critique assumes that property rights such as rights to land present a useful economic benchmark for how property rights, especially the right to exclude others, ought to function. ${ }^{199}$ Thus, their argument finding notice failure in patents is not that real property has no lessons for the patent system. ${ }^{200}$ In fact, as to liability, they see a "crucial" similarity between the two legal regimes in disregarding knowledge or intent for determining liability. ${ }^{201}$

Yet this comparison, correct so far as it goes, simply restates the conventional strict liability view of patent infringement ${ }^{202}$ while ignoring the tortious intent of an alleged infringer - or of an alleged trespasser. ${ }^{203}$ Instead, Professors Bessen and Meurer conclude that the patent system is not specific enough in delineating boundaries to justify property rights akin to those that guard against trespass to land. ${ }^{204}$

There is some force to the counterargument that Professors Bessen and Meurer's indeterminacy critique is unduly reductive of real property, e.g., their contrast between the scope of real property rights and the scope of patent rights. ${ }^{205}$ The full scope of a right in real property consists of temporal and functional boundaries in addition to physical ones, and the scope of an estate in real property is not captured solely, or even. primarily, by a fence around land. ${ }^{206}$ Rather, defining rights of

199. See generally BESSEN \& MEURER, supra note 126, at $29-45$ (drawing comparisons between the respective economics of tangible property rights and patent rights).

200. See id. at 30 (asserting that "the economics of property has valuable lessons for the economics of patents").

201. Professors Bessen and Meurer argue that "[a] trespasser is still liable regardless of whether she was mistaken about a property line or took care to avoid trespass. Similarly a technology-adopter is still liable for patent infringement regardless of whether she independently invented or made a good-faith effort to avoid intruding on someone's patent rights." Id. at 31 .

202. See supra Subsections I.A.1-2.

203. As previously discussed, there is no trespass to land where the unauthorized entry was unintentional and non-negligent. See supra note 193 and accompanying text.

204. BESSEN \& MEURER, supra note 126, at 46-72.

205. Professors Bessen and Meurer argue:

\begin{abstract}
The scope of tangible property is relatively easy to define in terms of physical attributes. For example, the scope of land rights is defined by a boundary traced on the earth. Defining the scope of patent rights is extremely difficult, because it is hard to draw a boundary around an idea.
\end{abstract}

Id. at 32. Similarly, Professor Tun-Jen Chiang has found the boundaries of patent rights lacking in clarity by comparison to the stability of fences around real property. See Tun-Jen Chiang, Fixing Patent Boundaries, 108 MiCH. L. REv. 523, 527-31 (2010).

206. See Mossoff, supra note 132, at 1698-99. Professor Adam Mossoff argues that comparing patent indeterminacy to land trespass alone is a logical fallacy in the conceptual sense, as it commits a category mistake. See id. at 1696-1704. He adds that the supposed clarity of notice as a bulwark against trespass to land is also unverified as an empirical matter. See id. at 1704-10. 
possession, use, disposition, and future interests, etc., is the greater task of real property, and in that exercise, construing the terms of wills, deeds, and similar documents is much like construing patent claims. ${ }^{207}$ Yet, this counterargument does little more than reduce the scope of patent indeterminacy to be evaluated, leaving open a more limited analogical role for trespass. Trespass has just such a role to play as to the specific doctrine of direct patent infringement. ${ }^{208}$ In fact, real property offers a variety of examples where tortious intent is necessary to create liability for trespass to land. ${ }^{209}$

Perhaps the simplest case of non-trespass for inadequate tortious intent is falling by accident onto another's land. For example, in Puchlopek v. Portsmouth Power Co.,${ }^{210}$ a schoolboy died when he slipped and his arm entered between two pickets of the fence that enclosed a transformer station, coming in contact with a high-voltage wire. ${ }^{211}$ Though the jury at trial accepted the power station's defense that the boy was a trespasser, the Supreme Court of New Hampshire disagreed, finding that the boy's arm entered onto the power station's land involuntarily, which could not constitute trespass. ${ }^{212}$ Quite apart from whether the boy intended to commit trespass or knew who owned the power station, the court focused on the simple fact that he had not intended to enter the land. ${ }^{213}$

Trespass also fails where a third party physically forces the would-be trespasser to either enter the land or remain there. Thus, in Hayes $v$. Bushey, ${ }^{214}$ the Supreme Court of Maine held that a truck driver who had left the highway and crashed into a building was not liable because he had been driving lawfully with due care, and another driver's car forced him off the road. ${ }^{215}$ Similarly, in Feiges v. Racine Dry Goods Co.,${ }^{216}$ the owner of a dry goods store had been unable to leave the building to which his lease was due to expire because a picket line of striking employees had blocked all entries and exits. ${ }^{217}$ The Supreme Court of Wisconsin

207. See Mossoff, supra note 132, at 1699-1700.

208. See Vishnubhakat, supra note 131, at 40 (arguing that rather than generalizing up to the level of estate boundaries as Professor Mossoff suggests, the patent indeterminacy debate should "ask what subsidiary doctrine of patent law is commensurate in analytical scope with the doctrine of trespass in real property" and proposing direct patent infringement as that subsidiary doctrine).

209. See supra notes $183-86$ and accompanying text.

210. 136 A. 259 (N.H. 1926).

211. Id. at 259 .

212. Id. at 260 .

213. Id.

214. 196 A.2d 823 (Me. 1964).

215. Id. at 826 .

216. 285 N.W. 799 (Wis. 1939).

217. Id. at 799 . 
found no trespass, holding that although the store owner had physically remained past his permission to do so, he had no intent to stay and the "stress of circumstances" prevented him from leaving. ${ }^{218}$

These cases reflect settled common law property principles requiring an intent to enter land for trespass liability to arise. ${ }^{219}$ Just as an action for trespass protects a real property right against a direct invasion of the underlying subject of the right (the land), an action for direct infringement also protects a patent right from direct invasion of the underlying subject of that right (the invention). In operationalizing that analogous role, the intentional tort theory of infringement draws much from the history and principles of trespass to land. ${ }^{220}$

Though largely ignored and untheorized by patent law, the tortious intent inquiry also comports with the language of the Patent Act and provides a potential resolution for an important practical debate currently taking place in patent infringement law.

\section{B. Tortious Intent in Patent Infringement}

However well grounded the doctrine of tortious intent may be in common law tort principles, it must also rest on the statutory foundations of the U.S. patent system. In fact, not only does the text of the direct patent infringement statute support an inquiry into tortious intent, but federal appellate case law on statutory interpretation confirms the textual argument.

\section{The Statutory Basis for Tortious Intent}

The Patent Act regards as a direct infringer "whoever without: authority makes, uses, offers to sell, or sells any patented invention, within the United States or imports into the United States any patented invention during the term of the patent therefor.",221

The use of four transitive verbs_-"makes," "uses," "offers," and "sells"-to specify the set of infringing actions is consistent with requiring purposive action on the part of an alleged infringer. The level of purpose may be as minimal as seeking to accomplish the natural result of the act itself or to believe that such a result is substantially certain to follow, e.g., an alleged infringer must seek to accomplish the result of selling something: the sale of the thing. Whether the alleged infringer was additionally mistaken or wholly ignorant of the act's legal consequences is neither necessary nor sufficient for determining liability. Indeed, this

218. Id. at $801-02$.

219. See supra Subsections II.A.1-3.

220. See supra Section II.A.

221. 35 U.S.C. $\$ 271$ (a) (2012). 
is the very conception of intent in tort law. ${ }^{222}$

As a matter of statutory construction, federal courts have similarly read the use of transitive verbs in statutes as calling for purposive action. In Cole v. United States Attorney General, ${ }^{223}$ for example, the U.S. Court of Appeals for the Eleventh Circuit upheld the denial of a Jamaican citizen's petition for asylum, ${ }^{224}$ finding that his state criminal conviction in South Carolina was a disqualifying "crime of violence" for deportation purposes. ${ }^{225}$ Following the Supreme Court's instruction in Leocal v. Ashcrofi ${ }^{226}$ that a crime of violence requires a mens rea greater than mere negligence, ${ }^{227}$ the court in Cole found that the relevant South Carolina statute making it "unlawful for a person to present or point at another person a loaded or unloaded firearm" 228 suffices because the transitive verb "presenting" refers to "showing or displaying a firearm in a threatening or menacing manner' and hence requires an intentional mens rea."229

Similarly, in United States v. Hill, ${ }^{230}$ the U.S. Court of Appeals for the Sixth Circuit reversed the dismissal of criminal charges of aiding and abetting a gambling enterprise, finding that the so-called "illegal gambling business" statute ${ }^{231}$ may support felony accomplice liability if, but only if, the aider and abettor demonstrates adequate intent. ${ }^{232}$ Following its own instruction in United States v. Bryant ${ }^{233}$ that aiding and abetting as a general matter requires specific criminal intent, ${ }^{234}$ the court in Hill found an appropriate intent requirement in the statute's "six transitive verbs-'conducts, finances, manages, supervises, directs, or owns" - denoting the actions that the accomplice's own actions must have endorsed to be liable. ${ }^{235}$

222. See supra note 182 and accompanying text.

223. 712 F.3d 517 (11th Cir. 2013).

224. Id. at 520 .

225. 18 U.S.C. $\$ 16$ (defining a "crime of violence").

226. 543 U.S. 1 (2004).

227. Id. at $9-11$.

228. S.C. CODE ANN. \& 16-23-410 (2015) (emphasis added).

229. 712 F.3d at 528 (quoting In re Spencer R., 692 S.E.2d 569, 572 (S.C. Ct. App. 2010)). More precisely, Cole accepted the South Carolina appellate court's interpretation of the statute because the Eleventh Circuit independently found that "this interpretation of the active verb is consistent" with more general state supreme court precedent about the elements of the state statute. $I d$.

230. 55 F.3d 1197 (6th Cir. 1995).

231. 18 U.S.C. $\$ 1955(2012)$.

232. Hill, 55 F.3d at $1198-99$.

233. 461 F.2d 912 (6th Cir. 1972).

234. Id. at 920 .

235. 55 F.3d at 1202 (parsing the text of 18 U.S.C. $\S 1955$ ). 
The Supreme Court in Flores-Figueroa v. United States ${ }^{236}$ elaborated on this thread of statutory construction, taking it as implicit that a transitive verb in statutory text calls for purposive action and finding further that an adverb of intentionality that modifies such a verb also modifies both the object of the verb and limitations on the object. ${ }^{237}$ The defendant had been convicted under the federal aggravated identity theft statute, which holds liable anyone who "knowingly transfers, possesses, or uses, without lawful authority, a means of identification of another person.,"238 However, the Government had not proven or found it necessary to prove the defendant's knowledge that the means of identification belonged to another person. ${ }^{239}$ Eight members of the Court, including Justices Antonin Scalia and Clarence Thomas concurring in pertinent part, reversed the conviction and agreed that the statute's mens rea requirement extended not only to the purposive actions denoted by the transitive verbs ("transfers," "possesses," and "uses"), but also to the object of those verbs ("means of identification") and to the modifier of that object ("of another person"). ${ }^{240}$ Justice Alito, for his part, limited his" concurrence only to reject an inflexible rule of construction whereby the mens rea requirements of federal criminal statutes might routinely apply. to every element of an offense. ${ }^{241}$

It seems uncontroversial as a general matter of construction, therefore, that the use of transitive verbs in the direct patent infringement statute calls for purposive action on the part of the alleged infringer and that the requisite level of purpose be at the minimal standard of tortious intent: to seek to accomplish a making, an offering, a selling, or a using.

\section{The Common Law Basis for Tortious Intent}

The widespread acceptance of direct infringement as a strict liability offense is problematic because the strict liability designation originally arose as an inference from what direct infringement does not requireintent to infringe, knowledge of the patent, and so on-but the designation has since become a starting premise for the infringement determination itself. ${ }^{242}$ Yet strict liability is itself an incomplete inference and therefore an inapt premise, as it ignores an important element of determining direct patent infringement: whether there is an intent to

236. 556 U.S. $646(2009)$.

237. Id. at $650-52$.

238. 18 U.S.C. $\$ 1028 \mathrm{~A}(\mathrm{a})(1)$ (emphasis added).

239. Flores-Figueroa, 556 U.S. at 648.

240. See id. at 650-54; id. at 657 (Scalia, J., concurring in part and concurring in the judgment).

241. Id. at 659 (Alito, J., concurring in part and concurring in the judgment).

242. See supra note 42 and accompanying text. 
perform the act that constitutes infringement.

The basis for inquiring into an alleged infringer's intent to perform such actions already exists implicitly in the direct infringement jurisprudence, in cases dating as far back as the early twentieth century. In Brothers v. United States, ${ }^{243}$ for example, the plaintiff asserted a patent on improvements in cableways on gravity anchors whereby the towers connecting the cables would desirably yield or tilt. ${ }^{244}$ During construction of the Panama Canal, the U.S. government had built rigid cableway towers that happened to yield or tilt under the stress of tightened cables, and the patentee argued that this was infringement. ${ }^{245}$ The U.S. Court of Claims found noninfringement, however, because the government's towers were rigid by design, and unintended mechanical behavior in the towers that happened to coincide with the patented invention was not infringement. ${ }^{246}$

Likewise, in Pratt $v$. United States, ${ }^{247}$ the plaintiff asserted a patent on a mechanism for hooking an airplane in flight to a stationary arresting apparatus and thereby gradually slowing the airplane's speed to land it in very short distance. ${ }^{248}$ The U.S. government employed a mechanism on its naval aircraft carriers designed for hooking an airplane that had already landed on the deck and thereby slowing only its forward progress, though at times the government's mechanism did happen to hook an airplane while the airplane was still technically in flight; on this basis, the patentee argued infringement. ${ }^{249}$ The Court of Claims again found noninfringement, holding that if a device was constructed and intended to operate on a different principle than what the patent involved and intended, then inadvertent or unskillful operation that happened to coincide with the patented invention was not infringement. ${ }^{250}$ In both cases, the court found direct noninfringement, not because the defendant was unaware of the patent or because it did not intend to infringe, but because it did not intend to perform the underlying actions that constituted infringement.

This basis for direct noninfringement has survived into modern Federal Circuit jurisprudence as well. In Pall Corp. v. Hemasure, ${ }^{251}$ for example, plaintiff Pall Corporation asserted a patent on a venting system

243. 52 Ct. Cl. 462 (1917).

244. Id. at 466 .

245. Id.

246. Id.

247. 43 F. Supp. 461 (Ct. Cl. 1942).

248. Id. at 461,475 .

249. Id. at $475-76$.

250. Id.

251. 181 F.3d 1305 (Fed. Cir. 1999). 
for filtering leukocytes from blood using porous membranes to prevent the passage of air into a filtration chamber. ${ }^{252}$ Defendant Hemasure's filtration system contained similar porous membranes, but Hemasure did not intend these membranes to filter air from blood. ${ }^{253}$ Accordingly, the court held that the divergent purpose of the membrane precluded liability for direct infringement even if the accused system appeared literally to infringe. ${ }^{254}$ Conversely, in Centillion Data Systems v. Qwest Communications, ${ }^{255}$ plaintiff Centillion asserted a patent on a system for a service provider to gather, process, and deliver information to a customer. ${ }^{256}$ Defendant Qwest argued that there was no directly infringing "use" of the patented system by accepting customer queries and performing the back-end processing itself, rather than allowing customers to use the entire system autonomously. ${ }^{257}$ The court, however, found direct infringement, reasoning that a customer's engagement of the system by creating a query causes the remainder of the system to "act for its intended purpose" and therefore is enough to create a directly infringing use. ${ }^{258}$ In these modern cases, too, the finding of direct. infringement (or not) has turned on whether the alleged infringer's conduct, whether by designing toward or away from a particular purpose, reflected an intent to perform the actions that constitute infringement. ${ }^{259}$

Importantly, the findings in these cases concerning what the patented inventions were actually designed to accomplish are examples of purposive construction in evaluating the scope of patent rights. This approach to construction is altogether appropriate, for just as the tortious intent refers to that purposive action of the alleged infringer that violates the patent, purposive construction of the patent itself refers to what invention the inventor intended for the patent to protect. ${ }^{260}$

Despite this implicit role for tortious intent in direct patent infringement-quite apart from knowledge of a patent or intent to infringe it-courts and commentators alike have mistakenly persisted in describing direct patent infringement as a strict liability offense. ${ }^{261}$ The

252. Id. at $1307-08$.

253. Id at $1310-11$.

254. Id. at 1312 .

255. 631 F.3d 1279 (Fed. Cir. 2011).

256. Id. at 1281 .

257. Id. at $1284-85$.

258. Id. at 1285 .

259. See, e.g., MLMC, Ltd. v. Airtouch Commc'ns, Inc., 215 F. Supp. 2d 464, 475 (D. Del. 2002) (discussing the act of intentionally designing away from another patent as evidence of noninfringement).

260. See infra Subsection III.E.2.

261. See, e.g., In re Seagate Tech., LLC, 497 F.3d 1360, 1368 (Fed. Cir. 2007); Potter Voice Techs., LLC v. Apple Inc., 24 F. Supp. 3d 882, 885 (N.D. Cal. 2014) (quoting In re Seagate, 497 
mistaken strict liability conception, in turn, has had important consequences for the role of indeterminacy and notice in the patent system.

\section{TOWARD A NEW VIEW OF DIRECT INFRINGEMENT}

The focus of Part II has been to fill the doctrinal gap identified in Part I regarding direct patent infringement by defining a doctrine of tortious intent that connects purposive action to tort liability, particularly in the unresolved controversy over divided infringement. Part III now places the doctrine of tortious intent in context with larger open questions about patent infringement and identifies several important benefits that this doctrine offers in the ongoing patent policy debate.

\section{A. Direct Infringement as an Intentional Tort}

The mistaken view that direct patent infringement is a strict liability tort and the identification of a precisely defined inquiry into the purposive actions of the alleged infringer point to a straightforward-though perhaps dissonant-conclusion. The basic act of infringing a patent is best understood as an intentional tort.

It has been necessary to refer separately to an underlying tortious intent because patent law separately imposes penalties for infringement that stems from knowledge or reckless ignorance ${ }^{262}$ of legal rights or an intent to infringe, whether through willful infringement ${ }^{263}$ or through induced or contributory infringement. ${ }^{264}$ Where these particular forms of knowledge or intent are unnecessary, patent law has declared strict liability. ${ }^{265}$ Yet the definition of intent in the tort law sense is modest enough to fit even what little space remains for purposive action when all other requirements of willfulness, recklessness, or knowledge are gone. In direct patent infringement, as in the rest of tort law, intent denotes only "that the actor desires to cause consequences of his act, or that he believes that the consequences are substantially certain to result from it."266

F.3d 1360); Arlington Indus., Inc. v. Bridgeport Fittings, Inc., 692 F. Supp. 2d 487, 510 (M.D. Pa. 2010).

262. See supra notes $47-51$ and accompanying text (discussing the willful infringement standard, which previously required actual knowledge or notice of the patent as articulated by Underwater Devices); supra notes 45-46 and accompanying text (discussing the current Seagate standard, which permits a finding of willfulness based on recklessness on the part of the infringer).

263. See supra notes $45-54$ and accompanying text (discussing the role of knowledge and intent in willful infringement).

264. See supra notes 55-62 and accompanying text (discussing the role of knowledge and intent in induced infringement and contributory infringement).

265. See supra Subsection I.A.1 (discussing what was historically meant by a "strict liability" view of patent infringement).

266. RESTATEMENT (SECOND) OF TORTS $§ 8$ A (AM. LAW INST. 1965); see supra notes 182 89 and accompanying text. 
This elementary and overlooked view of intent offers theoretical support for at least four important doctrinal entry points into the debate over boundary notice in the patent system. A first entry point is the need to differentiate among makers, sellers, and users of inventions that turn out to be patented. This is an economically significant distinction to make when evaluating and allocating the costs and risks associated with avoiding infringement, but it is a distinction for which patent law currently offers no principled approach. A second entry point is the recent jurisprudential shift in the doctrine of inherency away from traditional requirements of recognition of the conduct in question, with regard to prior art anticipation as well as to infringement. A third entry point is the challenge of divided infringement, which the Supreme Court confronted but left ultimately unresolved in its October 2014 Term. A fourth entry point is the proper approach to ex post claim construction by courts once a patent owner has asserted its rights against alleged infringers, particularly those whose conduct may reside in a zone of uncertainty that is outside the scope of the patented invention but inside the scope of the.patent claim language.

\section{B. Makers vs. Sellers vs. Users}

In some respects, treating direct infringement as an intentional tort makes little immediate difference; in other respects, considerable difference. And that difference is precisely the point.

\section{Intent to Make an Invention}

For technology implementers acting in a variety of economic circumstances, the act of making an invention is already purposive. Among simple articles of manufacture, for example, where a patent covers a chair comprising four legs, a seat, and a back, it is unlikely that a manufacturer of stools that comprise four legs and a seat will possess the tortious intent to infringe the patent. To do so, the manufacturer would have to set out to build a stool and unintentionally build a chair. To be sure, more complicated facts abound, particularly in industries that operate at microscale and nanoscale. Such manufacturing operations may, indeed, run afoul of patents either despite designs to the contrary or simply from ignorance. Recent case law addressing such truly inadvertent infringement is discussed in detail later in this Article. ${ }^{267}$ In the main, however, the deliberate design, antecedent detail, and often high fixed cost of establishing manufacturing operations suggest that an entity will usually have the tortious intent to make an invention that does, or does not, infringe a patent. The doctrine of tortious intent does little to disrupt this state of affairs. 


\section{Intent to Sell an Invention}

Sales and offers for sale are a less straightforward case. The work of sellers, like that of manufacturers, is undoubtedly purposive at the basic level of intending to sell something. Depending on the complexity of the good or service being sold, however, there may or may not be tortious intent with specific regard to a particular patented invention. For example, the stool manufacturer's distributor surely knows that the goods she is selling are stools rather than chairs. Yet a smartphone manufacturer's distributor may well be unaware that the goods she is selling include chipsets that are based on a reduced instruction set computing (RISC) architecture. ${ }^{268}$ If so, she would lack the tortious intent to sell such a chipset and would not be liable for infringing a patent that covered such chipsets. Notably, an upstream component vendor that sold chipsets to the smartphone manufacturer likely would not be so ignorant in this regard. Hence, the manufacturer would likely possess the tortious intent to sell and be liable for infringement, all else equal. This practical importance of an actor's position in the stream of commerce is a sensible result of the doctrine of tortious intent because it tends to create liability among those actors who are well positioned at lowest cost to avoid infringement ${ }^{269}$ and tends to alleviate the risk of liability among those actors who are not so well positioned or for whom the cost of informing themselves of technical details are impractically higher in light of their downstream commercial and nontechnical roles as, for example, distributors or retailers.

\section{Intent to Use an Invention}

Using is the case for which the doctrine of tortious intent offers the most powerful flexibility as a doctrinal lever. In part this is because what constitutes use in patent law is multiform. One important set of users for

268. Rachel Courtland, The Battle Between ARM and Intel Gets Real, IEEE SPECTRUM (Apr. 25, 2012, 16:09 GMT), http://spectrum.ieee.org/semiconductors/processors/the-battle-betweenarm-and-intel-gets-real.

269. This conclusion rests upon a large body of law and economics literature regarding the allocation of risk and cost to those whose activities give rise to relevant accidents and harms "[o]nly if it can clearly be shown that injurers could have cheaply avoided the loss." See Guido Calabresi, Torts-The Law of the Mixed Society, 56 TEX. L. REv. 519, 519 (1978). To put the principle more formally, "economic efficiency asks for that combination of entitlements to engage in risky activities and to be free from harm from risky activities which will most likely lead to the lowest sum of accident costs and of costs of avoiding accidents." Guido Calabresi \& A. Douglas Melamed, Property Rules, Liability Rules, and Inalienability: One View of the Cathedral, 85 HARV. L. REV. 1089, 1094 (1972) (emphasis added). Importantly, this least-cost-avoidance principle does not systematically foreordain liability for any one class of parties, whether it be the injurer or the injured, for "[a]s often as not, the best decision maker is the victim." Guido Calabresi, Civil Recourse Theory's Reductionism, 88 IND. L.J. 449, 456 (2013). 
whom tortious intent is a particularly timely doctrinal innovation is end users. End users, who may be broadly understood as the eventual and ultimate consumers of an integrated technology, have been exposed to patent infringement liability at various points in U.S. history. One example is the assertion of dormant agricultural patents against farmers during Reconstruction. ${ }^{270}$ Another example is the threat by patent lawyer George Selden, who held a broad patent on automobiles generally, against would-be customers of the Ford Motor Company that to purchase a Model $\mathrm{T}$ was to "[b]uy a [1]awsuit." 271 End users remain equally important in the current debate over patent litigation and patent notice, particularly in cases where patent owners assert their rights against allegedly infringing manufacturers (who are accused of making the patented invention), against allegedly infringing distributors and retailers (who are accused of selling the patented invention), and finally against customers at the end of the stream of commerce (who are accused of using the patented invention). ${ }^{272}$

Among the variety of proposals aimed at empowering end users in the face of such patent assertions, two of note include targeted fee shifting for prevailing end users ${ }^{273}$ and an explicit customer-suit exception. ${ }^{274} \mathrm{Fee}$ shifting is a pragmatic departure from the usual American Rule requiring each party to pay its own way. ${ }^{275}$ Alternatively, the current customer-suit exception, a procedural case management mechanism, is a relatively obscure common law practice of staying end user litigation until the courts have resolved upstream lawsuits against the accused manufacturer. ${ }^{276}$

By comparison, the doctrine of tortious intent offers a direct substantive reply to such end user litigation practices, whatever their

270. Gerard N. Magliocca, Blackberries and Barnyards: Patent Trolls and the Perils of Innovation, 82 NOTRE DAME L. REV. 1809, 1811 (2007).

271. Robert P. Merges \& Richard R. Nelson, On the Complex Economics of Patent Scope, 90 CoLum. L. REV. 839, 888-90, 890 n.217 (1990).

272. Gaia Bernstein, The Rise of the End User in Patent Litigation, 55 B.C. L. REv. 1443, 1443-44 (2014) (discussing threatened and actual litigation by patent assertion entities against end users). Professor Gaia Bernstein argues that patent owners in such cases have no need to cultivate relationships with customers and so are not deterred from asserting their rights in ways that practicing patent owners would be. Id. at 1455-56. This, together with a large pool of potential alleged infringers and a high likelihood of settling rather than exploring the merits of a litigation at great cost, has led to a proliferation of economically inefficient end user litigation. Id. at 1447, 1470 \& n. 175 .

273. Id. at 1450 .

274. Brian J. Love \& James C. Yoon, Expanding Patent Law's Customer Suit Exception, 93 B.U. L. REv. 1605, 1614 (2013).

275. See John F. Vargo, The American Rule on Attorney Fee Allocation: The Injured Person's Access to Justice, 42 AM. U. L. REV. 1567, 1575-76 (1993).

276. See, e.g., Rates Tech. Inc. v. N.Y. Tel. Co., No. 94 Civ. 9297 (DC), 1995 WL 438954, at $* 2$ (S.D.N.Y. July 25,1995$)$. 
prevalence or severity may be as an empirical matter. Whereas manufacturers by virtue of their direct purposive engagement with the making of technologies are likely to possess the tortious intent to make, and whereas sellers may or may not possess the tortious intent to sell depending on their position in the stream of commerce, end users are more unlikely than any other economic actors to possess the tortious intent to use the kinds of highly integrated inventions that pose the greatest problems of notice. Accordingly, end users' lack of tortious intent in such cases would substantively shield them from liability for the intentional tort of direct patent infringement.

\section{Inherency and the Anticipation-Infringement Symmetry}

Second, with respect to inherency, the doctrine of tortious intent provides a potential resolution for the Federal Circuit's controversial emerging jurisprudence in the doctrines of both anticipation and infringement.

\section{The Anticipation Doctrine}

Anticipation is a legal conclusion that a given invention is not novel because the invention was previously patented, described in a printed publication, or in public use. ${ }^{277}$ Regardless of the source of anticipation, the features of the invention as presently claimed must all be present in a single source-the "all elements rule"-for novelty to be destroyed. ${ }^{278}$ If the elements of the invention are dispersed over two or more prior sources, then the nonobviousness requirement is the appropriate standard for evaluating whether the invention is patentable. ${ }^{279}$ The all elements rule also governs infringement such that an accused device must contain every limitation of an asserted patent claim, either literally or equivalently, to infringe the claim. ${ }^{280}$ As this shared use of the all elements rule reflects, U.S. patent law has long recognized a symmetry between anticipation and infringement. ${ }^{281}$ The usual articulation of this symmetry is "[t] hat which infringes, if later, would anticipate, if

277. 35 U.S.C. $\S 102(a)$ (2012).

278. Net MoneyIN, Inc. v. VeriSign, Inc., 545 F.3d 1359, 1369 (Fed. Cir. 2008).

279. See 35 U.S.C. $§ 103$; Alfredo De La Rosa, A Hard Pill to Swallow: Does Schering v. Geneva Endanger Innovation Within the Pharmaceutical Industry?, 8 COLUM. SCI. \& TECH. L. REV. 37, 44 (2007).

280. TIP Sys., LLC v. Phillips \& Brooks/Gladwin, Inc., 529 F.3d 1364, 1379 (Fed. Cir. 2008).

281. Int'l Seaway Trading Corp. v. Walgreens Corp., 589 F.3d 1233, 1239 (Fed. Cir. 2009) (finding it "well established for over a century that the same test must be used for both infringement and anticipation"). 
earlier." $^{, 282}$

\section{The Inherency Doctrine}

Yet the all elements rule is not the end of the story. To it, the courts have added the common law principle of inherency, which holds that although some necessary element may not expressly be identified, the law may still consider the element to be present if it is inherent in the given technology. ${ }^{283}$ For example in Abbott Laboratories $v$. Geneva Pharmaceuticals, Inc. ${ }^{284}$ the Federal Circuit found inherent anticipation and so invalidated a patent on an anhydrate crystal formulation of a drug for treating hypertension and benign prostatic hyperplasia. ${ }^{285} \mathrm{~A}$ third party not involved in the litigation had previously sold the compound in the United States, and although none of the parties to those transactions had known which particular anhydrate crystal they were transacting at the time, the court found that the product sold had inherently possessed each of the limitations of the asserted patent claim. ${ }^{286}$ Accordingly, the sales anticipated the patented invention, and the asserted claim was invalid. ${ }^{287}$

Importantly, the doctrine of inherency traditionally included a requirement that an inherent element could contribute to anticipation only if people of ordinary skill in the art know or appreciate the inherent element. ${ }^{288}$ For example in Tilghman v. Proctor ${ }^{289}$ the Supreme Court upheld a patent on a process for separating natural fats into fatty acids and glycerine by applying high temperature and high heat to a mixture of natural fats and water. ${ }^{290}$ An earlier steam cylinder had been in use that happened to subject tallow, which was used to lubricate the piston, to a similar combination of high temperature and high heat and thus produced some quantities of fatty acids and glycerine as incidental waste products. ${ }^{291}$ The Court declined to find inherency, explaining that the

282. Peters v. Active Mfg. Co., 21 F. 319, 321 (C.C.S.D. Ohio 1884), aff'd, 129 U.S. 530, 537 (1889).

283. See Cont'l Can Co. USA, Inc. v. Monsanto Co., 948 F.2d 1264, 1268-69 (Fed. Cir. 1991) (discussing the weight given to the inherency doctrine when determining anticipation under 35 U.S.C. $\$ 102$ ).

284. 182 F.3d 1315 (Fed. Cir. 1999).

285. Id. at 1316,1319 .

286. Id. at 1317,1319 .

287. Id. at 1319.

288. Cont'l Can, 948 F.2d at 1268 (requiring that the inherent element "would be so recognized by persons of ordinary skill"). As to what is actually inherent, rather than what is merely probabilistic, the doctrine also requires that "the missing descriptive matter is necessarily present in the thing described in the reference." Id.

289. 102 U.S. $707(1880)$.

290. Id. at 709,734 .

291. Id. at $710-11$. 
prior accidental effects that coincided with the patent claims were "never fully understood" and occurred "accidentally and unwittingly ... without exciting attention." 292 Accordingly, the Court concluded that a finding of anticipation would be "absurd."

Similarly, in Eibel Process Co. v. Minnesota \& Ontario Paper Co. ${ }^{294}$ the Supreme Court upheld a patent on an improvement to the field of Fourdrinier paper-making machines. ${ }^{295}$ Prior to the patented invention, such machines began to produce defective paper when the rolling woven mesh belt on which the paper was formed moved faster than 500 feet per minute. ${ }^{296}$ Inventor William Eibel determined that the reason for this defect was that the mesh belt, known as the wire, was moving more quickly than the raw paper stock, leading to turbulence and rippling in the stock itself. ${ }^{297}$ Eibel solved this problem by sharply raising the slope of the wire and thus increasing the downward speed of the stock by the additional gravitational force so that the wire and stock would move at roughly equal speeds, allowing for better paper and faster production speeds. ${ }^{298}$ The validity of the patent was challenged based on an earlier patent to inventors Barrett and Horne whose invention had similarly raised the slope of the wire for water drainage-related purposes, and so the challenger argued accordingly that the earlier patent anticipated Eibel's patent regardless of "whether Barrett and Horne perceived the advantage of speeding up the stock to an equality with the wire, yet the necessary effect of their devices was to achieve that result." 299 The Court, citing Tilghman, reiterated the knowledge requirement for inherency that "accidental results, not intended and not appreciated, do not constitute anticipation." $" 300$

\section{The Role of Tortious Intent}

These historical affirmations-that knowledge, recognition, or appreciation of a putatively inherent element in the prior art are necessary to create anticipation and destroy novelty - have also been a doctrinal bulwark against creating liability for truly inadvertent infringement based on a theory of inherency. In SmithKline Beecham Corp. v. Apotex

\footnotetext{
292. Id. at $711-12$.

293. Id. at 712 .

294. 261 U.S. 45 (1923).

295. Id. at 46,69 .

296. Id. at 52 .

297. Id.

298. Id. at $52,55$.

299. Id. at 66 .

300. Id.
} 
Corp. ${ }^{301}$ however, the Federal Circuit dramatically enlarged the scope of inherent anticipation. ${ }^{302}$ As a result, the Federal Circuit's decision has created the symmetric potential for inherent infringement as well.

The SmithKline decision invalidated SmithKline's patent on crystalline paroxetine hydrochloride (PHC) hemihydrate, one of a class of chemical compounds invented during the late 1970s and possessing antidepressant properties. ${ }^{303}$ An earlier form of the paroxetine salt had been an anhydrate lacking any bound water molecules, whereas the more stable hemihydrate comprised PHC crystals with one water molecule for every two PHC molecules. ${ }^{304}$ The court held that the prior art anhydrate inherently anticipated the patented hemihydrate because producing the anhydrate necessarily produced trace amounts of hemihydrate. ${ }^{305}$ The court found it irrelevant that these trace amounts were not detectable at the time ${ }^{306}$ and were therefore incapable of being appreciated by those of ordinary skill in the art. Not coincidentally, the court in SmithKline also found that Apotex, by producing such trace amounts of PHC hemihydrate through its production of prior art PHC anhydrate, would have infringed SmithKline's patent. ${ }^{307}$ However, in view of the court's inherent anticipation finding, the finding of infringement carried no liability. ${ }^{308}$

The SmithKline decision has potentially profound ramifications for. the patent notice debate. By removing the inherency doctrine's historical sine qua non of knowledge, recognition, or appreciation, the Federal Circuit has bilaterally distorted the incentive structure underlying the patent system. On the one hand, because qualities inherent in a technology that were unappreciated even by those having ordinary skill in that technology may now create anticipation and defeat novelty, the ability of innovators to secure patent protection is weaker. ${ }^{309}$ No less important, however, is the implicit newfound ability of patent owners to impose infringement liability on a theory of inherent infringement against

301. 403 F.3d 1328 (Fed. Cir. 2005).

302. Id. at 1329 (granting petitions for rehearing en banc only for the limited purpose of vacating the original opinion on the issue of experimental use). The dissent expressed concern "that the court has preserved the [panel] opinion's enlargement of the ground of invalidity called 'inherent anticipation."' Id. (Newman, J., dissenting).

303. See SmithKline Beecham Corp. v. Apotex Corp., 403 F.3d 1331, 1334 (Fed. Cir.), aff'd en banc, 403 F.3d 1328 (Fed. Cir. 2005) (en banc).

304. Id.

305. Id. at $1341-42$.

306. Id.

307. Id. at 1346.

308. Id. at $1346-47$.

309. See, e.g., De La Rosa, supra note 279 , at 40-42, 48 (arguing that the broader scope of the inherent anticipation doctrine in SmithKline stands to impede the development by pharmaceutical companies of in vivo metabolites and other biological compositions). 
those whose conduct inadvertently constitutes practicing the patented invention. This is strict liability patent infringement in the true sense, and because no appreciation of the physical consequences of one's conduct is necessary for a finding of inherent infringement, the boundary notice function of patents and the opportunity to avoid infringement in this regime are wholly meaningless.

The doctrine of tortious intent provides a cure for this jurisprudential shift as well. Because tortious intent requires purposive action on the part of an alleged infringer ${ }^{310}$ and because purposive action is not possible without knowledge or appreciation of the underlying consequences of one's actions, ${ }^{311}$ the intentional nature of the direct infringement tort proposed here provides a natural check against such an unconstrained view of inherency, either for anticipation or for direct infringement. ${ }^{312}$

\section{Divided Infringement}

Third, on the issue of divided infringement, recent guidance from the Supreme Court has created the need for a coherent theoretical basis for ascribing intent to alleged infringers.

\section{Akamai and the Single-Entity Rule}

Before the Federal Circuit reheard Limelight Networks, Inc. v. Akamai Technologies, Inc. ${ }^{313}$ the Court rejected the doctrine that that an alleged infringer who performs only some of the steps of a patented method while encouraging another to perform the remaining steps may be liable for induced infringement even if no one was liable for an underlying direct infringement. ${ }^{314}$ The Federal Circuit had originally held en banc that such inducement liability could attach because inducement does not require that the underlying direct infringement create liability, only that direct infringement occurred: to satisfy this limited latter condition, it is enough

310. See supra Section II.B (elucidating the operation of the doctrine of relevant intent in patent infringement).

311. See supra notes $182-89$ and accompanying text (discussing the long-understood relationship between appreciation of the physical consequences of one's conduct and purposive action in the sense of intent).

312. But see Dan L. Burk \& Mark A. Lemley, Inherency, 47 WM. \& MARY L. REv. 371, 38182 (2005) (advancing a "public benefit" theory of inherency that foundationally rejects the knowledge or appreciation requirement in traditional inherency doctrine and, accordingly, commends the Federal Circuit's turn in SmithKline). Professors Burk and Lemley follow their argument as to anticipation to its conclusion in infringement, acknowledging that direct patent infringement will, indeed, be a true strict liability offense. Id. at 401 n. 150 .

313. 134 S. Ct. 2111 (2014), remanded for reh'g en banc, 797 F.3d 1030 (Fed. Cir. 2015) (en banc).

314. Id. at 2115. 
that the related parties perform all the steps of the patented method. ${ }^{315}$

Though the en banc Federal Circuit did not originally address direct infringement liability where the infringement is divided among different actors acting at arm's length, ${ }^{316}$ two dissents from that opinion argued that the issue cannot be avoided because direct and induced infringement are not separable in the way that the majority proposed. ${ }^{317}$ Following the Supreme Court's reversal, the Federal Circuit reheard the divided direct infringement issue and expanded its direct infringement ruling. ${ }^{318}$

\section{The Role of Tortious Intent}

The policy concern of the en banc Federal Circuit majority reflects the potentially significant impact of divided infringement upon the role of purposive action in direct patent infringement. The majority sought to abrogate the single-entity rule ${ }^{319}$ because where multiple actors at arm's length "share performance" of the steps in a patented method, "the patentee has no remedy, even though the patentee's rights are plainly being violated by the actors' joint conduct. ${ }^{\text {"320 }}$ With divided infringement now necessarily a question of direct infringement, however, true strict liability that disregards any intent whatsoever cannot furnish the purposive action necessary to "share" performance or to produce "joint"

315. Akamai Techs., Inc. v. Limelight Networks, Inc., 692 F.3d 1301, 1308-09 (Fed. Cir. 2012) (en banc) (per curiam), rev'd, 134 S. Ct. 2111 (2014).

316. The en banc question in Akamai was whether the direct infringement doctrine should preserve the so-called "single-entity rule" whereby all steps in a patented method must be performed by, or attributable to, a single entity for liability to arise. See Akamai Techs., Inc. v. Limelight Networks, Inc., 419 F. App'x 989, 989-90 (Fed. Cir. 2011).

317. See Akamai, 692 F.3d at 1319 (Newman, J., dissenting); id. at 1337-38 (Linn, J., dissenting).

318. See Limelight, $134 \mathrm{~S}$. Ct. at 2117 ("Assuming without deciding that the Federal Circuit's holding in Muniauction [that the single-entity requirement for direct infringement is appropriate] is correct."); id. at 2120 (observing pointedly that "on remand, the Federal Circuit will have the opportunity to revisit the $\S 271$ (a) question [that direct infringement requires a single entity] if it so chooses"). On rehearing, the Federal Circuit held that "Section 271(a) is not limited solely to principal-agent relationships, contractual arrangements, and joint enterprise, as the vacated panel decision held. Rather, to determine direct infringement, we consider whether all method steps can be attributed to a single entity." Akamai Techs., Inc. v. Limelight Networks, Inc., 797 F.3d 1020, $1023(2015)$.

319. Though the Supreme Court identified the single-entity rule with the decision in Muniauction, Inc. v. Thomson Corp., 532 F.3d 1318, 1329-30 (Fed. Cir. 2008), Muniauction had built on the earlier holding in BMC Resources, Inc. v. Paymentech, L.P., 498 F.3d 1373, 1380-82 (Fed. Cir. 2007), overruled by Akamai Techs., Inc. v. Limelight Networks, Inc., 692 F.3d 1301 (Fed. Cir. 2012) (en banc) (per curiam), rev'd, 134 S. Ct. 2111 (2014). The en banc Federal Circuit majority in Akamai wrote to address the conflict in past rulings on the single-entity rule of both Muniauction and BMC. Akamai, 692 F.3d at 1318-19 (majority opinion) (overruling BMC).

320. Akamai, 692 F.3d at 1305-06. 
conduct in a meaningful sense. ${ }^{321}$

Put another way, any theory of direct infringement that purports to account for divided infringement must show that legally distinct actors have, indeed, acted with some minimal cooperative purpose so that the law has a principled reason for treating their various partially infringing activities as a collective whole. The actors need not have any joint or individual intent to infringe a patent, nor even any joint or individual knowledge that such a patent exists - but to be cooperative, their actions must proceed from a purpose to accomplish a mutually known and intended result. Without this minimal cooperative purpose as to the act itself, any liability for divided direct infringement would necessarily impose a joint penalty upon independent actors who need not have had any notice of each other's conduct. In fact, the Federal Circuit rehearing decision in Akamai proceeded along similar lines by defining divided infringement not by reference to particular forms of cooperation (such as the "direction or control" test or the "joint enterprise" test) but rather by reference to the fact of cooperation, i.e., whether all the steps were attributable to a single entity. ${ }^{322}$

The following example illustrates the inappropriateness of imposing direct infringement liability collectively on entities that are purposively independent of each other.

- Acme Corp. holds U.S. Patent '816, issued in 2003 and expiring in 2020, whose only claim is directed to a rolling chair assembly method comprising:

- Step 1: securing a first terminal end of each of four legs onto a first side of a first two-sided flat surface suitable for sitting;

- Step 2: securing a suitable wheel onto a second terminal end of each said leg; and

- Step 3: securing a second two-sided flat surface orthogonally onto a second side of said first two-sided flat surface.

- Since 2004, Betel, Inc. of South Carolina has produced floor seats whose assembly practices only the third step of the ' 816 Patent.

- Since 2010, independent and ignorant of Betel, Cassco Ltd. of Oregon has produced wheeled tables whose assembly practices only the first two steps of the '816 Patent.

- As neither Betel nor Cassco has practiced every step of the patent claim, neither entity alone is liable for direct infringement. ${ }^{323}$

321. See supra notes $237-38$ and accompanying text.

322. Akamai, 797 F.3d at 1022-23.

323. See Dawson Chem. Co. v. Rohm \& Haas Co., 448 U.S. 176, 188 (1980) (noting that direct infringement requires practicing "every single element" of the claimed invention). 
- Yet under a doctrine of divided direct infringement that requires no minimal cooperative purpose or tortious intent common to both Betel and Cassco, Acme could hold them jointly liable even though their geographic and temporal separations reflect their purposive independence from each other.

In short, a principled approach to the timely issue of divided patent infringement requires a legal basis for evaluating the alleged infringers' conduct collectively, and that legal basis must establish some minimal cooperative purpose to achieve a mutually known and intended result. The doctrine of tortious intent supplies this necessary purposive action proceeding from well-understood tort principles. Importantly, the doctrine of tortious intent does not impose any greater requirement, leaving intact the settled patent law that direct infringement does not require knowledge of a patent nor any intent to infringe it.

\section{E. Claim Construction}

Fourth, with respect to claim construction, the doctrine of tortious intent provides a conceptual vehicle for courts to engage more transparently in claim construction that is purposive rather than solely linguistic. $^{324}$

\section{Linguistic vs. Purposive Construction}

The U.S. patent system operates in a peripheral claiming regime in which claims describe the outer bounds of the invention rather than a central claiming regime in which claims describe the core principles of the invention. ${ }^{325}$ Consistent with the broad remit of this approach to claiming, patent rights are also defined primarily by reference to necessary and sufficient characteristics rather than by reference to exemplars from which the law must subsequently infer the appropriate scope of attendant legal rights. ${ }^{326}$ Given this focus on the patent claim as being both denotative of the invention and synonymous with the scope of

324. For a comprehensive theoretical treatment of the distinction between determining the linguistic meaning of claims (interpretation) and giving legal effect either to that interpreted meaning or to some other normatively appropriate meaning (construction), see Tun-Jen Chiang \& Lawrence B. Solum, The Interpretation-Construction Distinction in Patent Law, 123 Y ALE L.J. $530,546,553$ (2013).

325. See Hilton Davis Chem. Co. v. Warner-Jenkinson Co., 62 F.3d 1512, 1565 (Fed. Cir. 1995) (distinguishing between peripheral claiming and central claiming); Burk \& Lemley, supra note 129 , at $1744-46$ (same).

326. See Jeanne C. Fromer, Claiming Intellectual Property, 76 U. CHI. L. REv. 719, 732-34 (2009). 
exclusionary rights, ${ }^{327}$ it is not surprising that construction of patent claims is the essential step in evaluating infringement. ${ }^{328}$ As a practical matter, claim construction is frequently outcome-determinative of litigation itself. ${ }^{329}$ For all its importance, however, claim construction remains a highly contentious practice, not merely between individual litigants who maneuver for a strategically favorable reading of the claimsin-suit, but among courts and commentators who embrace divergent theories of how generally to construe claims and how not to.

This theoretical debate has two major dimensions. One is procedural and ultimately structural: the allocation of the authority to construe claims with some measure of finality or deference. As the Court explained in Markman, the legal conclusion of what claim terms mean has long been a question of law for de novo appellate review. ${ }^{330}$ The en banc Federal Circuit in Cybor further interpreted Markman to mean that claim construction is a pure question of law with no distinct subsidiary questions of fact. ${ }^{331}$ Recently, after more than fifteen years under $C y b o r$, the Federal Circuit, invoking stare decisis in Lighting Ballast, once again affirmed claim construction to be a pure question of law. ${ }^{332}$ The Supreme Court recently decided the issue in Teva Pharmaceuticals USA, Inc. v. Sandoz, Inc. ${ }^{333}$ Teva framed the issue as a conflict between a patent-

327. The succinct and oft-cited expression of this principle is Judge Giles Rich's maxim that "the name of the game is the claim," i.e., that claims define what is patented and, necessarily, give notice of what infringes and what does not. Giles S. Rich, The Extent of the Protection and Interpretation of Claims-American Perspectives, 21 InT'L REV. IndUS. Prop. \& COPYRIGHT L. 497, 499, 501 (1990).

328. See J. Jonas Anderson \& Peter S. Menell, Informal Deference: A Historical, Empirical, and Normative Analysis of Patent Claim Construction, 108 Nw. U. L. REv. 1,16 (2013).

329. See Kyle J. Fiet, Restoring the Promise of Markman: Interlocutory Patent Appeals Reevaluated Post-Phillips v. AWH Corp., 84 N.C. L. REv. 1291, 1292-93 (2006); Daniel J. Melman, Note, Post Markman: Claim Construction Trends in the Federal Circuit, RiCH. J.L. \& TECH. para. 2 (Spring 2001), http://jolt.richmond.edu/v7i4/note2.html; Stephanie Ann Yonker, Post-Phillips Claim Construction: Questions Unresolved, 47 IDEA: INTELL. Prop. L. REv. 301, 303 (2007).

330. Markman v. Westview Instruments, Inc., 517 U.S. 370, 384 (1995) (recalling that "[t]he first [element of a patent case] is a question of law, to be determined by the court, construing the letters-patent, and the description of the invention and specification of claim annexed to them" (quotations omitted) (citing Winans v. Denmead, 56 U.S. 330, 338 (1853))

331. Cybor Corp. v. FAS Techs., Inc., 138 F.3d 1448, 1455 (Fed. Cir. 1998) (en banc) (finding that "[n]othing in the Supreme Court's opinion supports the view that the Court endorsed a silent, third option - that claim construction may involve subsidiary or underlying questions of fact"), abrogated by Teva Pharm. USA, Inc. v. Sandoz, Inc., 789 F.3d 1335 (Fed. Cir. 2015).

332. Lighting Ballast Control LLC v. Philips Elecs. N. Am. Corp., 744 F.3d 1272, 1283-85 (Fed. Cir. 2014) (en banc) (addressing and rejecting various criticisms by reference to the precedential value of $C y b o r$ and the potential tumult of reversing that decision), vacated and remanded, 135 S. Ct. 1173 (2015).

333. Teva Pharm. USA, Inc. v. Sandoz, Inc., 135 S. Ct. 831 (2015). 
exceptionalist Federal Circuit doctrine that requires de novo review of the factual findings that a district court makes in support of its claim construction and the general command of Federal Rule of Civil Procedure 52(a), which requires review of such factual findings for clear error. ${ }^{334}$ The Court held that Rule 52(a) does apply to subsidiary facts in claim construction-thus abrogating Lighting Ballast-and that appellate review of such facts must be deferential. ${ }^{335}$

The question of appellate deference has important consequences for certainty and stability, especially because the net effect between horizontal and vertical certainty is not always clear a priori. ${ }^{336}$ These arguments have special force in patent claim construction, ${ }^{337}$ particularly in light of the vigorous debate over certainty in boundary notice for the patent system. ${ }^{338}$ Nevertheless, the procedural allocation of the power to construe is ultimately of second-order importance to the more immediate challenge confronting judges.

That challenge is the substantive question of how to construe patent claims. The Federal Circuit's authoritative articulation in Phillips v. AWH Corp. ${ }^{339}$ of the claim construction doctrine shed some light on the relative importance of various analytical tools but left unstated any systematic approach to the actual work of claim construction. ${ }^{340}$ This work includes evaluating intrinsic evidence of claim meaning such as the patent specification, ${ }^{341}$ prosecution history, ${ }^{342}$ and the fate of related and foreign applications, ${ }^{343}$ as well as a panoply of extrinsic evidence such as

334. Petition for a Writ of Certiorari at i, Teva Pharm. USA, Inc. v. Sandoz, Inc., $2014 \mathrm{WL}$ 230926 (2014) (No. 13-854) (stating the question presented).

335. $135 \mathrm{~S}$. Ct. at 835. On remand, the Federal Circuit applied the corrected standard of appellate review for the district court's claim construction-de novo review of the overall claim construction and clear error review of the facts underlying the claim construction-and reached the same outcome. Teva Pharm. USA, Inc. v. Sandoz, Inc., 789 F.3d 1335 (Fed. Cir. 2015).

336. Compare Pierce v. Underwood, 487 U.S. 552, 585 (1988) (White, J., concurring in part and dissenting in part) (anticipating greater predictability through de novo review in Equal Access to Justice Act cases because courts of appeals would not be obligated to uphold divergent but reasonable district court holdings), with Conkright v. Frommert, 559 U.S. 506, 517 (2010) (anticipating greater predictability through deferential review in Employee Retirement Income Security Act cases because employers could rely upon plan administrators rather than "unexpected and inaccurate plan interpretations that might result from de novo judicial review").

337. See supra notes $150-52$ and accompanying text.

338. See supra Section I.B.

339. See Phillips v. AWH Corp., 415 F.3d 1303, 1312 (Fed. Cir. 2005) (en banc).

340. See Peter S. Menell, Matthew D. Powers \& Steven C. Carlson, Patent Claim Construction: A Modern Synthesis and Structured Framework, 25 BERKELEY TECH. L.J. 711, 718 (2010).

341. Id. at $722-23$.

342. Id. at 723 .

343. Id. at $723-24$. 
"inventor testimony, expert testimony, dictionaries, and documentary evidence of how the patentee and alleged infringer have used the claim terms." 344

The animating principle of the Phillips approach is fidelity to the linguistic meaning of claim language, but such meaning is often not enough to produce a complete analysis of the claims. ${ }^{345}$ As a result, courts must make normative judgments about how much legal effect, if any, to give to the linguistic meaning of claims and, by comparison, how much legal effect to give to some other point of reference, such as their understanding of the inventive idea at the core of the patent. ${ }^{346}$ Indeed, a number of scholars have advocated for a return to the inventive idea of the patent as a way to manage perceived excesses both in the breadth of patent scope and the breadth of patent assertion. The strongest of these arguments is for an explicit and radical return to central claiming. ${ }^{347} \mathrm{~A}$ relatively milder argument is for a refocused view of peripheral claims as useful proxies in identifying the invention rather than as necessary synonyms of the invention itself. ${ }^{348}$ The interpretation-construction distinction offers a way to clarify that the task of identifying the invention is often a normative exercise beyond the linguistic meaning of claims. ${ }^{349}$ To this line of argument, the doctrine of tortious intent contributes further by enabling what is otherwise a desirably transparent but perhaps "politically costly" choice by judges: construing purposively. ${ }^{350}$

\section{The Role of Tortious Intent}

Purposive construction refers to deriving meaning from a document's text based on the purposes for which the document was constituted, whether the text is of a statute, a contract, or anything else. ${ }^{351}$ In the case

344. Id. at 725 .

345. See Chiang \& Solum, supra note 324 , at 535-36.

346. Id. at 565-66.

347. See Burk \& Lemley, supra note 129 , at 1747 (describing their own proposal as a radical, but useful, thought experiment and leaving open the question of whether the benefits of returning to central claiming would outweigh the costs).

348. See Liivak, supra note 152, at 42-43. Professor Liivak's proposal is a single analytical approach for navigating the embodiments disclosed in a patent. Id. at 43-44. For a more methodological argument that courts should choose from among various methodologies of construing claims to reach socially optimal claim scope, see Christopher A. Cotropia, Patent Claim Interpretation Methodologies and Their Claim Scope Paradigms, 47 WM. \& MARY L. REV. 49, 128 (2005).

349. Chiang \& Solum, supra note 324 , at 566 (cautioning that "to the extent that a judge chooses the linguistic meaning as his lodestar, the linguistic meaning may run out").

350. See id. at $\mathbf{5 8 5}$ (referring to construing a patent to save its validity, which is a special case of purposive construction).

351. See Nicholas Pumfrey et al., The Doctrine of Equivalents in Various Patent RegimesDoes Anybody Have It Right?, 11 YALE J.L. \& TECH. 261, 287 (2009). For a concise history of 
of patents, purposive construction is the analysis of patent claims with a view to what they exist to protect: the inventor's invention. ${ }^{352}$ In fact, the controversy in Phillips was such a case.

Phillips was nominally about how to understand the term "steel baffle" in the context of Edward Phillips's invention for a noise-, fire-, and impact-resistant steel building material, which was particularly suited for deflecting bullets. ${ }^{353}$ Phillips was unable to prove infringement by AWH Corporation under a claim construction where the patent failed to cover steel baffles that did not deflect bullets due to their perpendicular orientation to the adjoining wall faces; rather, the patent covered only steel baffles that were oriented at an oblique or acute angle to deflect bullets. ${ }^{354}$ The en banc Federal Circuit divided over whether the linguistic meaning of "steel baffles" in the "798 Patent was limited to those steel baffles which deflect bullets. ${ }^{355}$

There is force to Professors Tun-Jen Chiang and Lawrence Solum's argument that the majority as well as the dissent in Phillips unproductively focused on the linguistic meaning of the term "steel baffles." 356 That term was neither ambiguous nor vague, though it may have rendered the patent overly broad if the court had read the term in its plain, linguistic meaning. ${ }^{357}$ In fact, implicitly and opaquely, the Phillips majority did just that, adopting a theory of construction that would give effect to the linguistic meaning, whereas the dissent favored the purpose of the invention rather than the linguistic meaning of the claims. ${ }^{358}$ The court would have done better to articulate transparently that its task was to decide whether and to what extent to give legal effect to this linguistic meaning. ${ }^{359}$ Yet neither theory of construction is inherently preferable to the other. Distinguishing claim interpretation from claim construction is a highly useful exercise, but ultimately it is a descriptive one.

The doctrine of tortious intent, too, is amenable to either approach of construction, though it does allow purposive construction to be more

purposive construction as a tool for construing written instruments and applying that history to patent construction, see Catherine Ng, The Purpose of "Purposive Construction," 15 INTELL. Prop. J. 1 (2000).

352. See Pumfrey et al., supra note 351, at 287.

353. Id. at 1310-11; U.S. Patent No. 4,677,798.

354. Phillips v. AWH Corp., 415 F.3d 1303, 1309 (Fed. Cir. 2005) (en banc).

355. Id. at 1312-19.

356. Chiang \& Solum, supra note 324 , at 536 (describing the court's approach as "a fool's errand" because the true dispute was over whether to give legal effect to the linguistic meaning of "steel baffle" and thus "arguably extend the monopoly scope of the patent to something that the patentee had not really invented").

357. Id.

358. Id. at $569-70$.

359. See id. 
transparent. ${ }^{360}$ There is simply nothing in the record of the Phillips case showing that AWH Corporation had no intention to build steel supports containing steel baffles that were perpendicular to the adjoining wall faces and as such could not deflect bullets. Thus, there was clearly tortious intent to do something of interest. Whether that something constitutes infringement depends on how the court ultimately construes the claims. However, while conceptually agnostic, the doctrine of tortious intent is particularly well-suited for purposive claim construction because it mitigates the aversion that courts may have to making their normative choices in claim construction explicit. ${ }^{361}$ The Phillips dissent, by focusing on its own understanding of what Edward Phillips actually invented rather than on the text of the '798 Patent, clearly and necessarily disrespects the USPTO examination that produced the overbroad patent. ${ }^{362}$ Rather than soften this conclusion through a linguistic distortion of what the claim must mean, however, it is preferable to engage expressly in a purposive construction that is more clearly justified because the alleged infringer's tortious intent does not extend to making, selling, or using what the patentee's invention actually is. As with the interpretation-construction distinction, this is not to say that a purposive approach is necessarily preferable, only that transparent purposivism is preferable and that the doctrine of tortious intent offers a way to be more transparent.

In fact, a basis already exists in the case law for this link between purposive claim construction and tortious intent. Both early and modern examples of tortious intent, including the previously discussed Pratt ${ }^{363}$ and Pall Corp. ${ }^{364}$ are examples of purposive claim construction. In Pratt, the infringement dispute was clear enough. The asserted patent covered a mechanism that hooked an airplane in flight to a stationary arresting apparatus and thus gradually retarded the airplane's vertical and forward speed to land it in a very short distance. ${ }^{365}$ The alleged infringing mechanism on the government's naval aircraft carriers, by design, hooked an airplane that had landed on the deck and thus retarded only its forward progress. ${ }^{366}$ To arrive at this technical, factually specific distinction between the patented invention and the allegedly infringing invention, however, the court construed the patent specifically with an eye to naming its purpose and, incidentally, to preserving its validity:

360. See supra note 324 and accompanying text.

361. See Chiang \& Solum, supra note 324, at 585.

362. See id.; Phillips v. AWH Corp., 415 F.3d 1303, 1332-33 (Fed. Cir. 2005) (en banc).

363. See supra notes $248-50$ and accompanying text.

364. See supra notes $252-54$ and accompanying text.

365. Pratt v. United States, 43 F. Supp. 461, 475 (Ct. Cl. 1941).

366. Id. 
In the instant case, it would not be a proper application of the purpose of the patent laws to construe plaintiff's assumed patent for a device to retard the speed of a plane while still in flight so broadly as to prevent the development and use by others of a device to stop the roll of a plane after it has touched the landing surface. The two ideas are different. Indeed, plaintiff's asserted novelty lay only in the accomplishment of the former, since the latter was plainly anticipated. $^{367}$

The court also made plain the connection between its purposive approach to construction and the pragmatic importance of what the defendant did and did not intend to do:

But because the whole problem arises out of the necessity for landing planes on a surface of limited area, and because the accomplishment of the feat is at best a hazardous one involving great skill, the defendant, desiring to retard the speed of the plane after it has touched the surface, should not be compelled, in order to avoid infringement, to waste a considerable amount of the limited landing area by locating its transverse cables so far forward on the deck that its planes will never engage one of the cables until after they have touched the landing surface. ${ }^{368}$

Likewise, in Pall Corp., the asserted patent covered a venting system for filtering leukocytes from blood through porous membranes that prevent the passage of air into a filtration chamber. ${ }^{369}$ Like the court in Pratt, the court in Pall Corp. bounded its construction of the patent by its understanding of the purpose of the invention itself:

We deem the district court's claim construction to be unduly broad. The '321 patent explains that the invention is directed to facilitating the air-driven gravity flow of blood through the leukocyte filter, reducing back pressure and minimizing air contact with the blood after the filtration is complete. The specification describes or suggests no role or location of the "gas outlet comprising a porous medium" other than to remove gas at the outlet of the system while retaining the blood and barring reentry of air. We conclude that the correct interpretation of claim clause [2] requires that the gas outlet porous medium be placed so as to serve that purpose. ${ }^{370}$

367. Id at 476 (emphasis added).

368. Id. (emphasis added).

369. Pall Corp. v. Hemasure Inc., 181 F.3d 1305, 1307 (Fed. Cir. 1999).

370. Id. at 1310 (emphasis added). 
These cases illustrate that the doctrine of tortious intent can valuably clarify the practical consequences of construing patent claims purposively, apart from the merits of purposivism itself. ${ }^{371}$ Indeed, the tortious intent of the alleged infringer and a purposive understanding of the patentee's claims are different sides of the same coin, for both reflect what was intended to be accomplished with respect to the given technology. This symmetry is, in fact, one that patent law has long recognized, connecting the patentee's desire to design around the prior art with the implementer's desire to design around the patent. ${ }^{372}$

\section{CONCLUSION}

The central argument of this Article has been that direct patent infringement is not a strict liability tort and that its designation is quite harmful given the high stakes of notice failure that true strict liability would implicate for the patent system. In place of this mistaken strict liability view, the text of the Patent Act and the historical understanding of patent infringement as an analogue of trespass in real property support a reframing of direct patent infringement as an intentional tort. The tortious intent of interest in this new doctrinal inquiry is an intent to perform an act that constitutes infringement: making, selling, or using an invention that happens to be patented. Neither a knowledge of patent nor any intent to commit infringement is necessary, just as they have been unnecessary for direct infringement thus far.

Moreover, the doctrine of tortious intent offers considerable practical benefit for a number of doctrinal debates currently ongoing in the patent system. First, it offers a conceptual basis for resolving the Supreme Court's incomplete recent Limelight decision regarding divided patent infringement. ${ }^{373}$ Second, it is consonant with the interpretation-

371. Related to the merits of construing patent claims purposively (i.e., based on the invention whose protection is the purpose of the patent) are the merits of construing patent claims with an eye toward the litigation outcomes of that construction. Professors Robert Merges and John Duffy argue, for example, that courts cannot help but interpret claims in the context of the particular infringement determinations that they face. See RoBerT P. MERGes \& John F. DufFy, Patent Law and Policy: Cases and Materials 907-08 (3d ed. 2002). Professors Dan Burk and Mark Lemley agree, and even suggest that this may be a strategically appropriate outcome in the adversarial civil litigation system. See Dan L. Burk \& Mark A. Lemley, Quantum Patent Mechanics, 9 LEWIS \& CLARK L. REv. 29, 50 (2005) (noting that "a judge's decision will effectively take the infringement decision away from the jury altogether in most cases by selecting a claim interpretation so constrained that it leaves no room for more than a single outcome" and arguing that "if a judge's construction doesn't have this effect, it likely means the patent lawyers on one side or the other haven't done their job").

372. Cf. Craig Allen Nard, A Theory of Claim Interpretation, 14 HARV. J.L. \& TECH. 1, (2000) (highlighting the coordination that occurs between the designers and the artists).

373. See supra Subsection III.B.1. 
construction distinction in analyzing patent claims and offers a normative justification for engaging transparently in purposive claim construction as part of the growing scholarly emphasis toward decoupling the invention from the peripheral claim. Third, it offers a jurisprudential cure both to the Federal Circuit's ill-advised expansion in the SmithKline decision of inherent anticipation doctrine and to that expansion's as-yetunrealized corollary, inherent infringement and its true strict liability consequences. ${ }^{374}$

Fourth, and most generally, the doctrine of tortious intent provides an explicit policy lever for mitigating the naturally divergent effects of patent boundary notice upon different economic actors depending on their place and function in the technological marketplace. The doctrine does so by exploiting the logical relationship between the specificity with which various economic actors engage with technology and the awareness, hence the purposive action, that the law may properly ascribe to those actors in possessing the tortious intent to perform the actions that may constitute infringement. Thus, manufacturers, who are likely to be most directly engaged, will tend most likely to act with tortious intent, and the doctrine will disrupt little in the current state of affairs. Sellers, who are likely to be engaged with greater variation depending on their place in the stream of commerce, will tend to act with tortious intent in proportion to their engagement with the technical details of the goods that they sell, and thus in proportion to their economically practicable ability to avoid infringement at low cost. And users, particularly end users who are likely to be least directly engaged with the technical details of inventions-especially highly integrated products comprising large numbers of component inventions-will tend least likely to act with tortious intent and will be most likely exempt from infringement liability. In this way, the doctrine of tortious intent also provides a systematic underpinning for various existing proposals to provide such a discriminant function within infringement doctrine, proposals that have thus far remained pragmatic departures from the general body of patent law. 